Research papers

\title{
Small-scale anthropogenic changes impact floodplain hydraulics: Simulating the effects of fish canals on the Logone floodplain
}

\author{
Apoorva Shastry ${ }^{\mathrm{a}, \mathrm{b}, *}$, Michael Durand ${ }^{\mathrm{a}, \mathrm{b}}$, Jeffrey Neal ${ }^{\mathrm{c}}$, Alfonso Fernández ${ }^{\mathrm{d}}$, Sui Chian Phang ${ }^{\mathrm{e}, 1}$, \\ Brandon Mohr ${ }^{\mathrm{f}}$, Hahn Chul Jung, ${ }^{\mathrm{g}, \mathrm{h}}$, Saïdou Kari ${ }^{\mathrm{i}}$, Mark Moritz ${ }^{\mathrm{j}}$, Bryan G. Mark ${ }^{\mathrm{b}, \mathrm{k}}$, \\ Sarah Laborde ${ }^{\mathrm{j}, 2}$, Asmita Murumkar ${ }^{\mathrm{b}, 3}$, Ian Hamilton ${ }^{\mathrm{e}}$ \\ ${ }^{a}$ School of Earth Sciences, The Ohio State University, 275 Mendenhall Laboratory, 125 South Oval Mall, Columbus, OH 43210, USA \\ ${ }^{\mathrm{b}}$ Byrd Polar and Climate Research Center, The Ohio State University, 136 Scott Hall, 1090 Carmack Rd, Columbus, OH 43210, USA \\ ${ }^{\mathrm{c}}$ School of Geographical Sciences, University of Bristol, Office 1 8Bn, University Road, Clifton, Bristol BS8 1SS, UK \\ ${ }^{\mathrm{d}}$ Department of Geography, Universidad de Concepción, Concepción, Chile \\ ${ }^{\mathrm{e}}$ Department of Evolution Ecology and Organismal Biology, The Ohio State University, 390 Aronoff Laboratory, 318 W. 12 th Avenue, Columbus, OH 43210, USA \\ ${ }^{\mathrm{f}}$ Department of History, and International Studies, The Ohio State University, 33 Townshend Hall, 1885 Neil Avenue, Columbus, OH 43210, USA \\ ${ }^{\mathrm{g}}$ Hydrological Sciences Laboratory, NASA Goddard Space Flight Center, 8800 Greenbelt Road, Greenbelt, MD 20771, USA \\ ${ }^{\mathrm{h}}$ Science Systems and Applications, Inc, 10210 Greenbelt Road, Lanham, MD 20706, USA \\ ${ }^{\mathrm{i}}$ Centre d'Appui a la Recherche et au Pastoralisme, Maroua, Cameroon \\ ${ }^{j}$ Department of Anthropology, The Ohio State University, 4058 Smith Laboratory, 174 W 18th Avenue, Columbus OH 43210, USA \\ ${ }^{\mathrm{k}}$ Department of Geography, The Ohio State University, 1136 Derby Hall, 154 North Oval Mall, Columbus, OH 43210, USA
}

\section{A R T I C L E I N F O}

This manuscript was handled by Emmanouil Anagnostou, Editor-in-Chief

Keywords:

Hydrodynamic modeling

Flood inundation mapping

Logone floodplain

Small-scale processes

\begin{abstract}
A B S T R A C T
Assessing the impact of climate change on floodplain productivity poses unique challenges for hydrodynamic models. For example, the dynamics of floodplain fisheries are governed both by inundation dynamics across thousands of $\mathrm{km}^{2}$, and water storage timing within small depressions (which serve as fish habitat) connected to the river network by meter-scale manmade canals, controlled by flow across fishing weirs. Here, we propose to represent these features as a system of effective, interconnected sub-grid elements within a coarse-scale model. We test this strategy over the Logone floodplain in Cameroon, and its floodplain fishery. We first validate this strategy for a local study area $\left(30 \mathrm{~km}^{2}\right)$; we find that hydraulic models at resolutions from $30 \mathrm{~m}$ to $500 \mathrm{~m}$ are able to reproduce hydraulic dynamics as documented by in situ water level observations. When applied to the entire floodplain $\left(16,000 \mathrm{~km}^{2}\right)$, we find that the proposed modeling strategy allows accurate prediction of observed pattern of recession in the depressions. Artificially removing floodplain canals in the model causes residence time of water in depressions to be overpredicted by approximately 30 days. This study supports the strategy of modeling fine-scale interconnected features as a system of sub-grid elements in a coarse resolution model for applications such as assessing the sensitivity of floodplain fisheries to future climate change.
\end{abstract}

\section{Introduction}

Predicting and modeling flood extent and timing is vital to understanding the dynamics of floodplain fish and fisheries (Thompson and Polet, 2000; Welcomme and Hagborg, 1977). Floodplain fish have evolved to flooding seasonality and their populations are driven by both flood and dry season duration, timing and magnitude. Depending on the location and season, floodplain fisheries employ various techniques to catch fish. Some techniques, like the use of fish canals, alter the drainage system, impacting flood extent, and timing of onset and recession of floods, which in turn affect the fish population and productivity (Delclaux et al., 2011; Laborde et al., 2016; Moritz et al.,

\footnotetext{
* Corresponding author.

E-mail addresses: shastry.7@osu.edu (A. Shastry), durand.8@osu.edu (M. Durand), j.neal@bristol.ac.uk (J. Neal), alfernandez@udec.cl (A. Fernández), sui.phang@port.ac.uk (S.C. Phang), hahnchul.jung@nasa.gov (H.C. Jung), moritz.42@osu.edu (M. Moritz), mark.9@osu.edu (B.G. Mark), s.laborde@griffith.edu.au (S. Laborde), murumkar.1@osu.edu (A. Murumkar), hamilton.598@osu.edu (I. Hamilton).

${ }^{1}$ Present address: Faculty of Business and Law, University of Portsmouth, Portsmouth, PO12UP, UK.

${ }^{2}$ Present address: Australian Rivers Institute, Griffith University, Nathan, Australia

${ }^{3}$ Present address: Department of Food, Agricultural and Biological Engineering, The Ohio State University.
} 


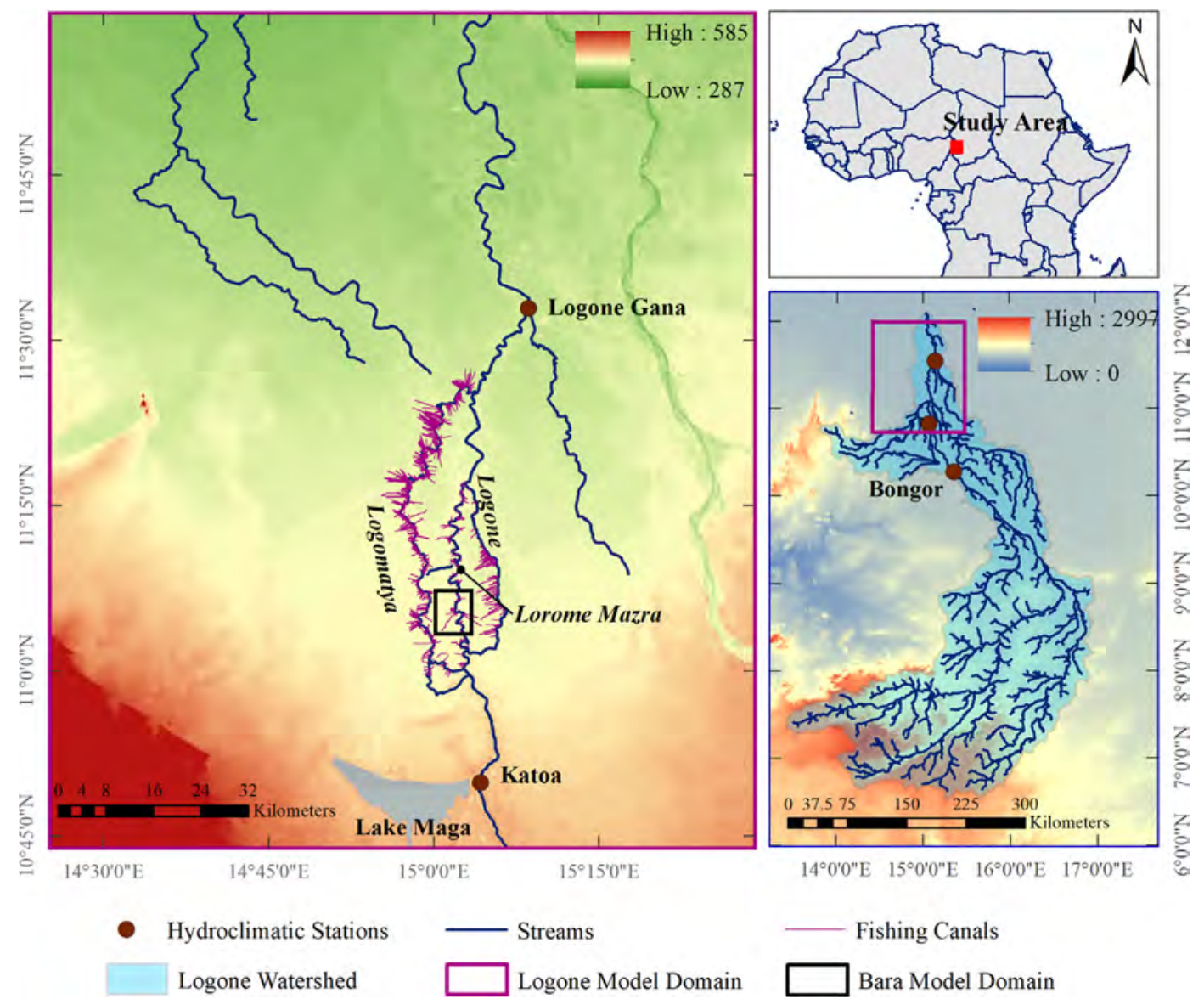

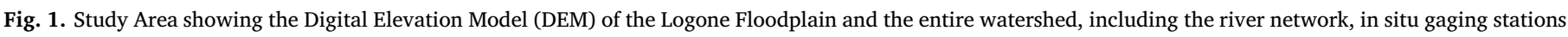
and fish canals.

2016). Future climate change is expected to produce changes in rainfall patterns and flows in river channels, which will also impact floodplain dynamics. In order to study the effects of floodplain fisheries and climate change on floodplain dynamics, researchers have turned to hydrodynamic models.

Hydrodynamic models are used to study complex links between hydrologic systems and social-ecological systems (Bockelmann et al., 2004; Casas-Mulet et al., 2014; DeVries et al., 2012; García et al., 2011; Nislow et al., 2002), and the impacts of climate change (Hirabayashi et al., 2013; O'Neill and Hulme, 2009). Hydrodynamic models predict the extent and timing of floods, and hence providing means to estimate some of the most critical parameters governing fish population in floodplain fisheries (Welcomme and Hagborg, 1977). Neal et al. (2012) introduced "sub-grid modeling", a strategy to systematically include and parameterize the effects of river channels smaller than the model grid scale in two-dimensional hydraulic models, a strategy that has opened the door to new applications (Kennedy et al., 2019; Komi et al., 2017; Schumann et al., 2016, 2013; Wing et al., 2017; Wood et al., 2016; Yamazaki et al., 2011). The need to estimate fish productivity and population for floodplain fisheries applications represent novel challenges to existing approaches, however.

In order for hydraulic models to be useful in the context of understanding floodplain fisheries, they will have to account for an interconnected system of elements functioning at sub-grid spatial scales. Natural floodplain depressions store water on floodplains, and provide habitat for fish to grow. Meter-scale, manmade canals link depressions and the river network, and provide means to harvest fish at the end of the season; weirs and fishnets are often installed on these canals, and modulate flow during recession. Such features are typically ignored in conventional hydrologic and hydrodynamic model simulations
(Fernández et al., 2016; Rajib et al., 2019). Sub-grid modeling provides the means of representing such features within a larger-scale model (Neal et al., 2012) that has primarily been used to represent small river channels must be adapted to represent this entire floodplain-depression-canal-river system of interconnected sub-grid features.

The objective of this paper is to describe and evaluate a strategy for hydrodynamic modeling that can be coupled with a canal-fishery model. We propose the following adaptations to traditional sub-grid modeling: i) We aggregate multiple fish canals and multiple depressions into a single effective model element to be represented as a sub-grid feature. ii) We treat depression storage as a sub-grid element, as well as the fish canals, thus creating an interconnected network of multiple types of sub-grid features. iii) We propose a strategy for modeling fishnet structures as weirs, as described below. Taken together, these approaches represent a distinct and novel strategy in hydraulic modeling.

We test this modeling approach in the Logone Floodplain in the Far North Region of Cameroon. We work from a previous study in this area that reproduced large-scale floodplain dynamics, but ignored fish canals and other small-scale processes important to hydraulic connectivity and fisheries (Fernández et al., 2016). We assess sub-grid modeling with a two-part strategy. First, we study a single depression with multiple canals over a $30 \mathrm{~km}^{2}$ area, and explore whether our strategy successfully captures observed water level dynamics as we vary the model spatial scale. Secondly we investigate whether a coarse scale $(500 \mathrm{~m})$ model of the entire floodplain $\left(16,000 \mathrm{~km}^{2}\right)$ is capable of reproducing inundation dynamics within floodplain depressions, which are sensitive to the presence of canals as demonstrated by Laborde et al. (2016). If demonstrated to adequately capture both local and floodplain scale dynamics, the sub-grid modeling approach will pave the way to 
couple hydrodynamic and fisheries models to study the impacts of the same small-scale features on fisheries. This type of modeling approach enhances our capacity to quantify and understand the effect of small canals in floodplains and flood-prone areas.

\section{Study area}

\subsection{Geography, hydrology and hydraulics}

The Logone Floodplain, also known as Yaayre, covers about $16,000 \mathrm{~km}^{2}$ (Delclaux et al., 2011), and is located in the Far North Region of Cameroon. It supports a large number of people with a population of about 200,000 (Laborde et al., 2016; Mitchell, 2013). The floodplain is a part of Lake Chad basin and contains the Waza National Park $\left(1700 \mathrm{~km}^{2}\right)$ and Kalamaloue National Park $\left(48 \mathrm{~km}^{2}\right)$. The floodplain is highly productive, and acts as breeding grounds for fish when inundated, and provides dry season pastures that support cattle and other livestock and fertile land for growing rice.

The Logone Floodplain is a small part of the Logone watershed and is located at the downstream part of the Logone River (Fig. 1). The floodplain has semi-arid climate, while the rest of the watershed has tropical wet and dry (Savannah) climate (Murumkar et al., 2020). The floodplain has mean annual rainfall of about $700 \mathrm{~mm}$; the upstream part of the watershed receives about $1200 \mathrm{~mm}$ annually (Evans and Loth, 2004a, 2004b; Murumkar et al., 2020). The first rainfall on the floodplain, generally in June/July, plays an important role by saturating the dry clayey soil, and overbank flow from Logone, Logomatya and Lorome Mazra river channels floods the region in September/October. The region is inundated for about three to four months (Delclaux et al., 2011; Jung et al., 2011). Local rainfall has less control over flooding than the flow in the Logone; overbank flow is the biggest contributor to the inundation of the floodplain (Evans and Loth, 2004a). Because the area is relatively flat, the flood spreads over a large area of about $8000 \mathrm{~km}^{2}$ (Delclaux et al., 2010) before it drains back to the Logone and the El Beid River in the north. The floodplain also experiences significant evapotranspiration throughout the year. Naah (1990) used piché evaporimeters and estimated the annual potential evaporation rate between $2700 \mathrm{~mm}$ and $3000 \mathrm{~mm}$ on the floodplain. However, it is important to note that maximum potential evaporation occurs between February and April when the floodplain is dry.

In the past decades, human activities have significantly modified floodplain dynamics. As a part of a large agricultural project, SEMRY II, for irrigated cultivation of rice, the Cameroonian government constructed a dam on the Logone in 1979, which created a $400 \mathrm{~km}^{2}$ reservoir (Lake Maga, Fig. 1) upstream of the floodplain (Loth, 2004). As a result of this, the flooding in the floodplain reduced by about $30 \%$ (Delclaux et al., 2010), which had a negative impact on the ecological and social systems in the floodplain (Loth, 2004; Scholte, 2005).

\subsection{Canal fisheries}

Fishing is an important regional livelihood on the Logone Floodplain (Delclaux et al., 2011; Laborde et al., 2016; Landolt, 2010; Loth, 2004). Fishing techniques used include fish traps, cast nets, gill nets, hooks and lines, grass fishing. Over the last half century, fish canals have gained popularity and their numbers have increased exponentially (Delclaux et al., 2011; Laborde et al., 2016).

Fish canals are man-made channels connecting the river to natural depressions in the terrain, which act as seasonal ponds (Fig. 2). Fishers dig new fish canals and maintain the old ones by removing the deposited sediments from the previous flood. These canals are used during flood recession to drain floodwater and channel fish moving off the floodplain through fishnets (Fig. 2(a)). The technique is effective because the fish canals can drain high volumes of water during the period of highest fish densities. Fig. 2(b) shows a photograph of a fish canal in the dry season, and Fig. 2(c) shows a photograph of an installed fishnet in a fish canal.

In the dry season, water is generally restricted to the rivers (see Fig. 1), Lake Maga and a few natural depressions. Floodwaters bring fish onto the floodplain; the inundated floodplain and natural depressions act as feeding and breeding grounds for fish. Fish population dynamics are driven by flooding patterns. The onset of flooding is typically when fish spawn, and the inundated floodplain provides a productive habitat for their primary growth period. Fish mortality is highest in the dry season when water volume is low because of high temperatures and low oxygen. Fish population biomass follows a 'boom-and-bust' pattern similar to floodplain water volume.

Floodplain fish production is driven by flooding patterns. Production has a positive relationship with flood magnitude and a negative relationship with dry season severity. Additionally, flood timing and aquatic habitat connectivity are also important variables in spawning and survival success. Understanding spatial and temporal patterns in flooding is necessary to evaluate the availability of a key natural resource for regional livelihoods.

However, fish canals connect the floodplain to the river and act as a hydraulic extension of the river drainage network. Increasing use of fish canals could potentially have effects on the flood dynamics with a change in inundation patterns or the timing of onset and recession of flooding. Our objective was to build a hydrodynamic model that captures the effect of these small-scale features, i.e. fish canals and fishnets, on flood inundation dynamics locally in the depressions and globally in the whole floodplain system.

\section{Methods and data}

\subsection{Hydrodynamic modeling of the Logone floodplain}

We used LISFLOOD-FP model to simulate hydrodynamic processes in rivers, floodplain, and fish canals. LISFLOOD-FP is a grid-based hydraulic model with one-dimensional channel representation and twodimensional floodplain representation based on a simplification of the shallow water equations (Bates et al., 2010; Bates and De Roo, 2000). It can represent small channels using a sub-grid scale parametrization of the channels' geometry and friction (Neal et al., 2012), where the channel is represented on a sub-grid scale by using parameters to represent channel geometry and friction. With sub-grid parametrization, rivers with widths smaller than the spatial resolution of the DEM can be simulated efficiently, and a separate 1D channel model is not necessary (Neal et al., 2012; Schumann et al., 2014a, 2014b). Simplified versions of the shallow water equations are then solved in the sub-grid channel and floodplain grid cell simultaneously. LISFLOOD-FP has been used to simulate inundation patterns for specific flood events (Bates et al., 2005; Neal et al., 2011) and to study long-term floodplain dynamics (Rudorff et al., 2014a, 2014b; Schumann et al., 2013), among other applications.

Using LISFLOOD-FP, we build hydrodynamic models at the Bara Depression (details in section 3.2), and of the larger Logone Floodplain (details in section 3.3 below). We build the Bara model at $30 \mathrm{~m}$ resolution to capture small-scale processes, and upscale it to $500 \mathrm{~m}$ while preserving the effects of these small-scale features. We then build a model of the Logone Floodplain at $500 \mathrm{~m}$ resolution to examine the effects of the small-scale processes on the larger system.

We introduce a new feature in LISFLOOD-FP to represent the fishnet structure, which is modeled as a combination of a weir and trashscreen. This feature is specially included for this application, and is not available in the standard version of LISFLOOD-FP. Fig. 2(c) shows a photograph of a fishnet in operation, and consists of sandbags to obstruct the flow which we represent as the weir, and a mesh made from twigs and leaves which we represent as the trash-screen. Water drop across the fishnet (Fig. 2(c)) is captured as a loss due to expansion and contraction of the flow area in the weir, caused by the acceleration of flow through the structure (Balkham et al., 2010). Equations (1), (2) 


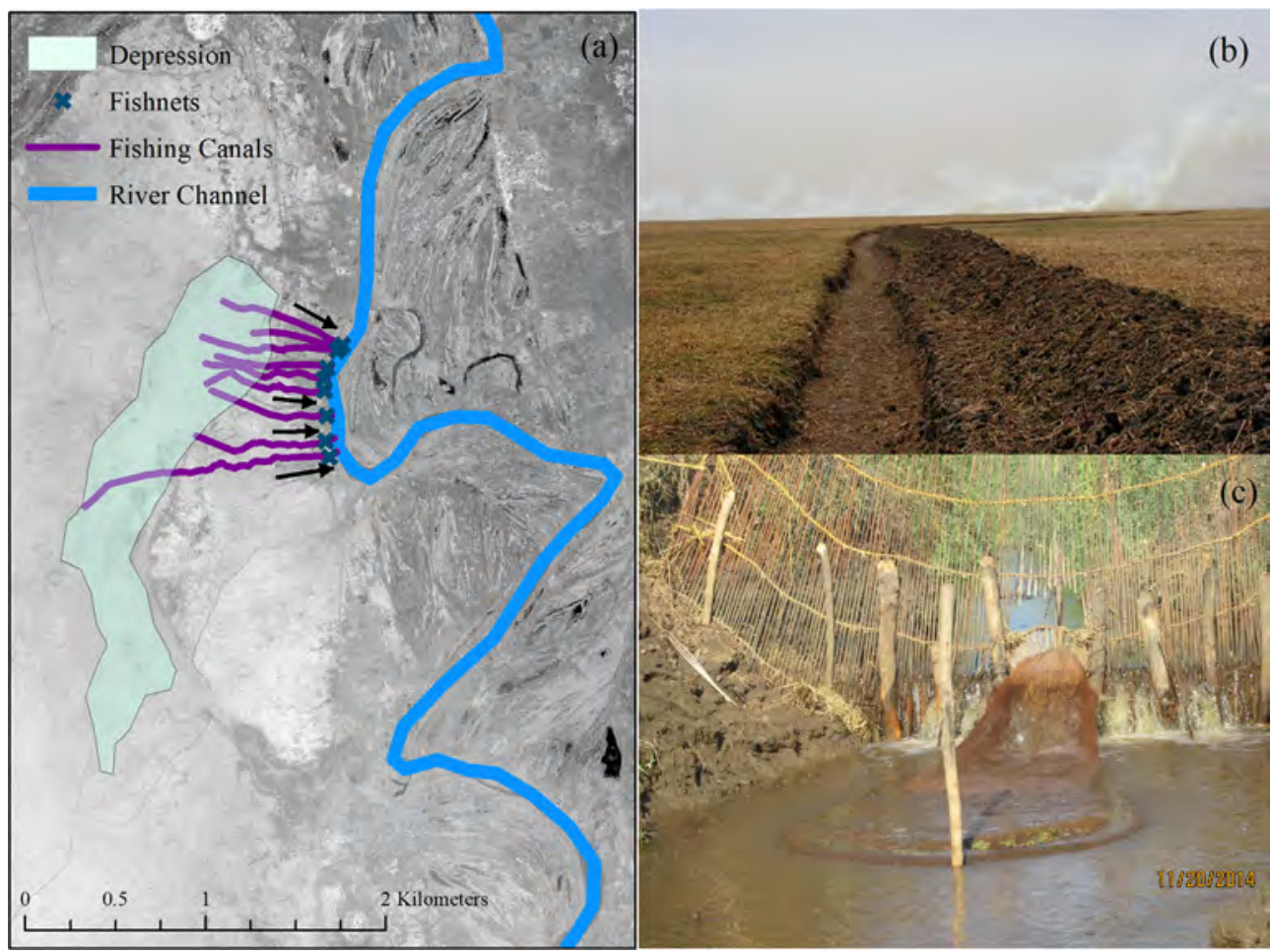

Fig. 2. Fish canals in the Logone Floodplain. (a) Schematic of flood recession process; black arrows represent the direction of flood recession to the river, blue cross represents the fish canals. (b) Photograph of a fish canal in the dry season. (c) Photograph of a working fishnet (ACEEN).

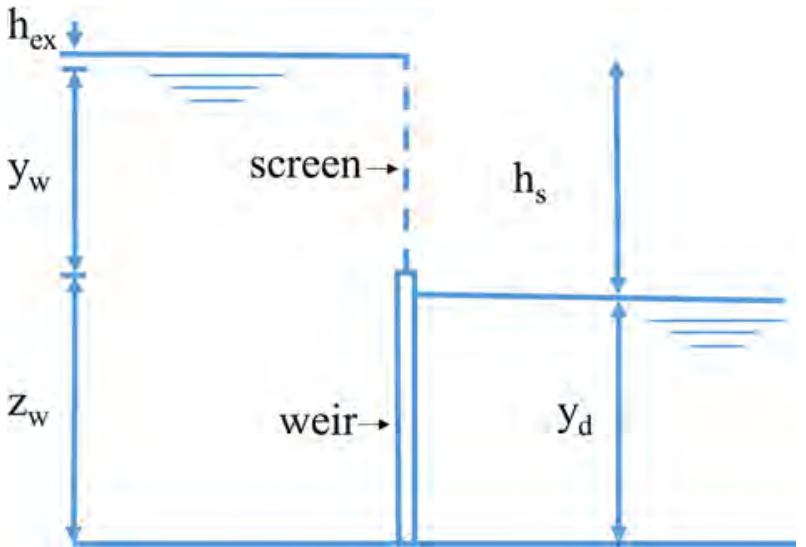

Fig. 3. Simple representation of the fishnet structure, showing the weir and the screen.

and Fig. 3 show the mathematical representation of this structure:

$h_{s}=\left(z_{w}+y_{w}+h_{e x}\right)-y_{d}$

where $h_{s}$ is the afflux of weir flow, $z_{w}$ is the height of weir crest, $y_{w}$ is the depth of weir flow over crest, $h_{e x}$ is head loss due to contraction and $y_{d}$ the downstream water depth.

$Q=C_{w} B^{\prime} y_{w}^{3 / 2}$

where $Q$ is the discharge in $\mathrm{m}^{3} / \mathrm{s}, C_{w}$ is the discharge coefficient for weir flow (typically between 1.4 and 1.7) and $B$ ' is the effective width at the screen $\left(B^{\prime}=\right.$ width ${ }^{*}$ screen coefficient $)$.

\subsection{Modeling approach: Bara}

The Bara region is a small area of about $30 \mathrm{~km}^{2}$ in the Logone Floodplain that we studied for understanding flooding dynamics. The site consists of a river channel, a depression of $\sim 1.1 \mathrm{~km}^{2}$, and nine fish canals that connect them. Lorome Mazra, the river channel in Bara, flows from South to North. To study the effects of fish canals and fishnets, we built a hydraulic model of Bara at a resolution of $30 \mathrm{~m}$ where each fish canal is individually represented, i.e., every fish canal is represented as a unique sub-grid channel. To quantify the impact of small-scale, local features captured in a coarser model, we also built a hydraulic model of the same Bara site at a resolution of $500 \mathrm{~m}$.

\subsubsection{Field data}

In the dry season of 2015, we surveyed the Bara depression using auto-levels to obtain the relative elevation profile of the depression. First, we established a reference point and recorded the location and ground elevation of this point using a GPS. Then, we recorded the locations and elevations of 97 sample points relative to the reference point using an auto-level. We performed ordinary kriging on this dataset to interpolate depression elevations at $30 \mathrm{~m}$ resolution. Fig. 4(a) shows the locations where we collected data, and the final product after ordinary kriging. We created a synthetic digital elevation model (DEM) of the region outside of the depression (Fig. 4(b)) by assuming that the floodplain has a slope of $10 \mathrm{~cm} / \mathrm{km}$ from south-to-north, as obtained from Shuttle Radar Topography Mission (SRTM) DEM as the mean slope along the entire floodplain. The interpolated data was burnt into the DEM to represent the depression.

In the summer of 2016, we surveyed all the fish canals in the Bara region and measured their width and depth at $50 \mathrm{~m}$ intervals. This data gave us information about the longitudinal and cross-sectional profiles of all the fish canals in Bara region. We used this data to parametrize the width and depth of all fish canals in this region.

We collected water depth measurements during the flood recession in all the representative features of the terrain (floodplain, depression, fish canal and river channel) (Laborde et al., 2018), to understand the coupling among them. A staff gage was installed in two locations for each feature, water depth was recorded in each location twice daily. Fig. 4(b) shows the locations of these measurements. Water depth measurements were recorded for eleven days between 8 and 22 


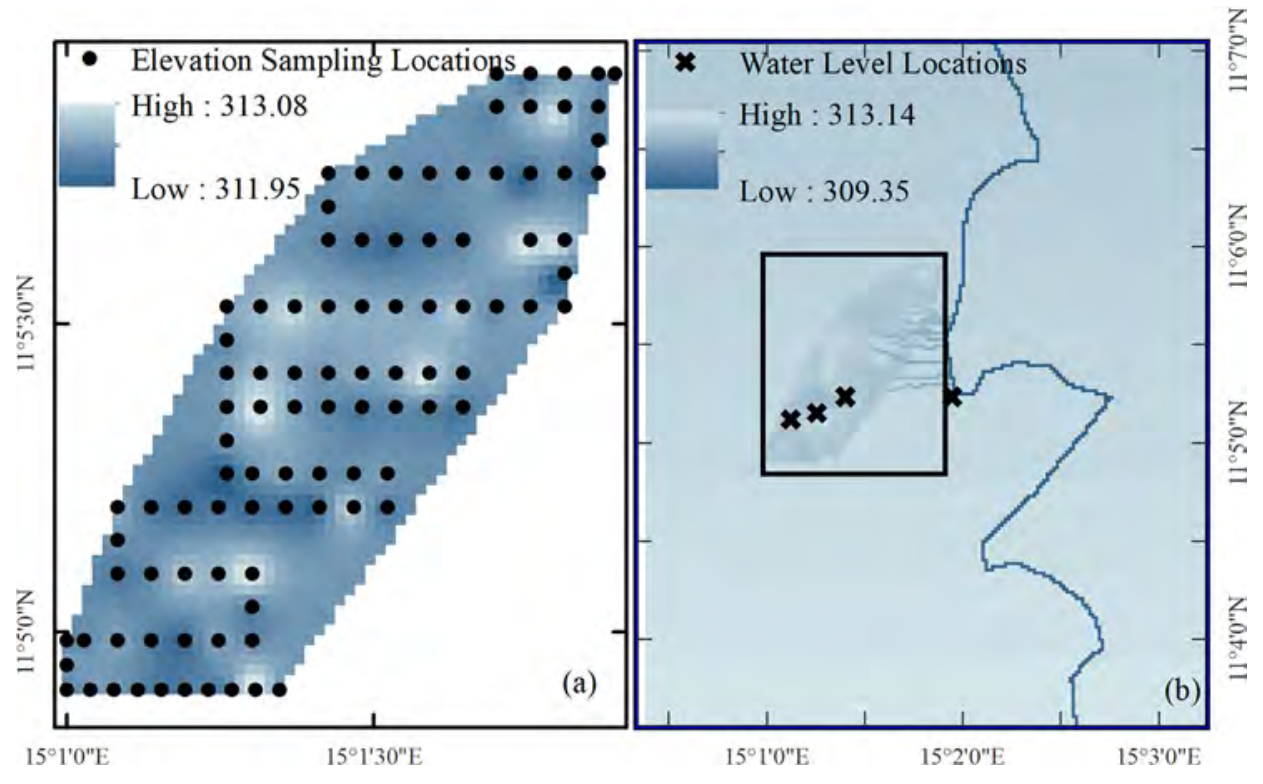

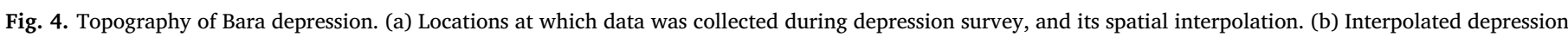
burnt into a synthetic topography.

November 2014 (no measurements between 13 and 16 November 2014). Daily mean water depth was obtained from the collected data, and the observed depth anomaly was used to evaluate the performance of the Bara model.

\subsubsection{Parametrization of river channel, fish canals and fishnets}

Bathymetry data was not available for the Lorome Mazra River, so we approximated channel geometry using remote sensing data. We used a 2009 satellite imagery from WorldView-1, which has a spatial resolution of $50 \mathrm{~cm}$, to estimate the width of Lorome Mazra to be $25 \mathrm{~m}$. From the field data collected in 2014, the mean depth of fish canals along Lorome Mazra was $1.3 \mathrm{~m}$ with the range between $0.1 \mathrm{~m}$ and $2.8 \mathrm{~m}$. The depth of the river channel has to be greater than the depth of fish canals. Using this and the knowledge of field experts, we assumed the depth of Lorome Mazra to be $3 \mathrm{~m}$, with an embankment of $60 \mathrm{~cm}$ height along the river.

In the $30 \mathrm{~m}$ model, the nine fish canals were represented as individual features. From the field data collected in 2016, we found that the mean width of the fish canals was $3 \mathrm{~m}$ and the mean depth of the canals near their start at the depression was $20 \mathrm{~cm}$. The canal bed sloped from the depression towards the river channel, with a mean bed slope of $60 \mathrm{~cm} / \mathrm{km}$.

We built the coarse resolution $(500 \mathrm{~m})$ model similar to the fine resolution Bara model. The river channel was represented as a sub-grid channel $25 \mathrm{~m}$ wide and $3 \mathrm{~m}$ deep. The fish canals were also represented as sub-grid channels, as in the $30 \mathrm{~m}$ model. However, each fish canal could not be represented individually, as multiple canals fell within a $500 \mathrm{~m}$ grid cell. If there was more than one fish canal in a grid cell, all the canals were aggregated such that the storage capacity of the aggregated fish canal was the same as the total storage capacity of all the fish canals falling in the grid cell. The width of the aggregated canal was calculated as the sum of average width of all the canals falling in a grid cell. A uniform depth of $0.5 \mathrm{~m}$ was assumed. An aggregated canal generally consists of 1 or 2 grid cells, so it wasn't feasible to define a bed slope gradient. The aggregated length was calculated by dividing the storage capacity of the $30 \mathrm{~m}$ model by width and depth of fish canals. The depression was also represented as a sub-grid feature, which preserved the volume of water stored in the depression from the fine resolution formulation. The depth of the depression was assumed to be uniform, as $0.5 \mathrm{~m}$ (mean depth of depression in the fine resolution model), and the length was calculated given the width of the cell was
$500 \mathrm{~m}$.

The fishnet used to capture fish works by channeling water flow in the canal through a small orifice which has a net attached. Sandbags are used to obstruct the flow. The mesh above the sand bags force the fish to move and be caught in the fishnet (Fig. 2(c)). In LISFLOOD-FP, we represented this feature as a combination of a weir and trash screen. Photographs collected during field data collection were used to approximate the width of the weir, which represented the orifice to which the fishnet was attached, and the crest height of the weir, which represented the depth of sandbags. We used field photographs to estimate the weir width as $0.5 \mathrm{~m}$ (1/6th times the average width of the fish canal) and crest height as $30 \mathrm{~cm}$. A trash screen coefficient was used to allow a portion of water to flow through the screen. We calibrated its coefficient value to produce the desired water drop across the fishnet and found that a trash screen coefficient of 0.8 produced a describable water drop across the fishnet of about $20 \mathrm{~cm}$ (ascertained from field photographs and knowledge of field experts).

\subsubsection{Boundary conditions}

There are no streamflow gages on the Lorome Mazra River, and hence, direct discharge observations were not available to set up this model. We obtained the upstream channel flow for the model from the Logone Model in Fernández et al. (2016). Bara is inundated each year from the overbank flow from the Lorome Mazra River, and the flood wave slowly moving from south to north in the floodplain. To represent the flood wave, we calibrated a time-varying water elevation boundary condition along the South boundary, as described in the following section. We used monthly open water evaporation rates from Naah (1990). We assumed that all precipitation was either infiltrated (before soil saturation) or evaporated, and did not include precipitation in the model (Fernández et al., 2018).

\subsubsection{Calibration of the Bara model}

We used the water level data collected during the flood recession of 2014 to understand the flood recession dynamics and we set up the Bara model with boundary conditions to recreate the same. A flow along the south boundary accounted for the flood wave moving into the Bara region from upstream. The depth of water entering along the south boundary was represented as a height boundary condition. We assumed that the floodplain was inundated for three months (Delclaux et al., 2011). Since we used a "semi-synthetic" DEM to build the Bara model, 
we needed a credible way to represent the flood wave flowing from south to north. We calibrated the depth of water entering the domain along the south boundary, and the onset of flood recession at Bara. The maximum flood depth $(60 \mathrm{~cm})$ and the timing of onset of recession $(5$ November 2001) were calibrated such that depth anomalies in the model for all the features (floodplain, depression, and fish canals) were similar to those observed in the field data.

\subsection{Modeling approach: Logone floodplain}

We built the large scale Logone model similar to the coarse resolution Bara model using LISFLOOD-FP, and quantified the effects of fish canals on the depressions by implementing a "no-canal" simulation. The model was simulated for a period of 7 years between 2001 and 2007. The details are described below.

\subsubsection{Topographic data}

Accurate topographic information is crucial for predicting flood inundation using hydrodynamic models. Airborne light detection and ranging (LiDAR) DEMs offer the best horizontal resolution and vertical accuracy. However, high resolution LiDAR DEMs are not available in the Logone Floodplain. The best available DEMs in this region were obtained from satellite data. SRTM DEMs are available globally at a spatial resolution of $30 \mathrm{~m}$; random error in their elevation accuracy in sub-Saharan Africa is $\sim \pm 2 \mathrm{~m}$ (Rodriguez et al., 2006), comparable to the flood depth in the Logone Floodplain (Delclaux et al., 2011). Hence, modeling with SRTM will produce spatial inconsistencies in inundation predictions (Fernández et al., 2016). The Multi-Error-Removed Improved-Terrain (MERIT) DEM (Yamazaki et al., 2017) was produced by removing multiple errors from existing globally available DEMs, and we used MERIT DEM in the present study. In the Logone Floodplain, absolute bias, stripe noise, speckle noise, and tree height bias were removed from SRTM DEM to get the MERIT DEM (Yamazaki et al., 2017).

We chose a coarse resolution $(500 \mathrm{~m})$ in order for the model to mimic spatial resolutions likely to be used when requiring computationally efficient simulations across future climate scenarios. Simulation at $500 \mathrm{~m}$ resolution allowed us to capture more of the depressions used for floodplain fisheries and was computationally more tractable than the $250 \mathrm{~m}$ resolution. Note that Fernández et al. (2016) found that $250 \mathrm{~m}, 500 \mathrm{~m}$ and $1000 \mathrm{~m}$ model simulations produced similar overall skill in reproducing inundation dynamics over the floodplain, albeit for a different model configuration. We resampled the MERIT DEM to $500 \mathrm{~m}$ using bicubic interpolation. We used a holefilling process to ensure that there were no troughs that acted as sinks in the DEM. All the channel banks in the floodplain were smoothed using a moving average filter using a window of $7 \times 7$ cells. This was done to ensure that the river channel did not have sudden changes in the terrain.

\subsubsection{Sub-grid parametrization of river channels, fish canals and depressions}

Similar to the Bara model, the river channels were represented as sub-grid elements. In LISFLOOD-FP, the locations of sub-grid channels are defined as regions. Each river channel was defined as a unique region; the Logone River was divided into two regions, approximately upstream and downstream of Logone Gana. Values for the different parameters (parameters controlling the depth of the channel given width, channel type and Manning's roughness coefficient) were defined for each region. For the model, we assumed that the channel was clean, straight with no rifts, and rectangular in shape, and used a Manning's n of $0.025 \mathrm{~s} / \mathrm{m}^{1 / 3}$ (Chow, 1959).

The width of all the channels were estimated from high resolution satellite imagery of the floodplain. The width of the Logone river ranged between $100 \mathrm{~m}$ and $400 \mathrm{~m}$. All other channels had widths less than $100 \mathrm{~m}$. The details of the calibration for river widths is given in Section 3.3.4.
In the Logone model, the fish canals were represented as sub-grid elements, similar to the representation in the $500 \mathrm{~m}$ Bara model. The widths of the fish canals were obtained from field data collected in 2013. The field data collection included the length of each canal in the Logone Floodplain, the width, depth and elevation at the start (depression) and end (river) of each fish canal. The dataset has information for 1286 fish canals. The mean length of a fish canal was $809 \mathrm{~m}$, and the median length was $533 \mathrm{~m}$. This meant that most fish canals were contained in 1-2 pixels (of $500 \mathrm{~m}$ resolution). Since it is not possible to define the slope obtained from the field data in one or two pixels, and most of the canals are not longer than two pixels, we used a constant depth to define its geometry. The mean depth of the fish canals was derived from the field data, and all fish canals were assumed to have a constant bankfull depth of $0.8 \mathrm{~m}$. The fish canals were represented as a unique sub-grid region with Manning's $n$ value of $0.025 \mathrm{~s} / \mathrm{m}^{1 / 3}$, similar to the river channels.

As in the $500 \mathrm{~m}$ Bara model, the depressions were also represented as sub-grid elements in the Logone model. The location and area of the depressions were obtained by depression mapping using satellite imagery. Supervised maximum-likelihood classification was performed on the cloud free imagery from the thermal infrared band of Landsat 5 (1986-87) and Landsat 7 (2000-03) during the dry season. We only considered the 48 depressions that had canals draining into them. In consultation with the field experts, we assumed that all the depressions had a constant depth of $1 \mathrm{~m}$. The fishnet was represented as defined in the Bara model. The parameters of the fishnet were retained from the calibrated Bara model.

\subsubsection{Boundary conditions}

In situ measurement of daily discharges were available at Katoa, Bongor and Logone Gana. Katoa is located at the upstream part of our study area, and the discharge measurements available here were used to define the upstream boundary condition. Bongor is located $\sim 60-\mathrm{km}$ upstream of Katoa, which is not included in the model domain. Previous studies suggest that the difference in discharge between Bongor and Katoa is due to overbank flow from the Logone that flows from south to north along the Chadian side of the Logone River (Naah, 1990; Seeber, 2013). To account for this flow on the Chadian side of the floodplain, as in Fernández et al. (2016), we assumed an additional flow on the east side of the Logone River as the difference in discharge between Bongor and Katoa in our model domain. Logone Gana is located in the domain of the model, downstream of Katoa. We used the discharge time series at Katoa and Bongor as the boundary conditions. We assumed a spin-up time of three months (May to July 2001) and considered the model predictions starting August 1st, 2001.

We did not provide a precipitation input for the model because flooding in the Logone Floodplain is dominated from overbank flow. We assumed that all the precipitation on the floodplain is either infiltrated or evaporated, and has no impact on the flooding (Fernández et al., 2018, 2016). Evaporation rates are high and we used monthly evaporation values from Naah (1990).

\subsubsection{Calibration of the Logone model}

Fernández et al. (2016) showed that even though the model captured the flow in the river channel, and hence channel to floodplain flow accurately, flood inundation maps produced from the model had spatial disagreement with observations. This disagreement can be attributed to error in topography, as it is the major remaining unknown. Mason et al. (2016) and Shastry and Durand (2019) both use different methods to modify topography for improving flood simulations. Here, we manually calibrated the MERIT DEM such that LISFLOOD-FP produced inundation maps that were more accurate. In the process of calibration, the DEM pixel elevations were altered such that water was forced to flow to the areas that were classified as inundated in the Landsat imagery. In other words, the pixel elevations of areas predicted by LISFLOOD-FP to be dry were reduced if the Landsat images classified 
them to be inundated, and vice versa. Flood inundation maps obtained from classified Landsat images (Fernández et al., 2016) in 2006 were used for this calibration.

Leopold and Maddock (1953) derived empirical relationships between river width, depth, discharge and catchment area based on extensive field measurements in over 100 river locations in the United States. These relationships have been used for multiple rivers in many previous studies since (Annis et al., 2019; Blöschl and Sivapalan, 1995; Camporese et al., 2010; Finnegan et al., 2005; Flint, 1974; Frasson et al., 2019; Gippel and Stewardson, 1998; Kim et al., 2019; Magilligan, 1992; Park, 1977; Pinter and Heine, 2005; Schumm, 1956; Tarboton et al., 1991; Whipple and Tucker, 1999; Yamazaki et al., 2011). This same geometric theory is used in the sub-grid formulation of LISFLOOD-FP (Neal et al., 2012), as this relationship can be used to estimate river geometry (Eq. (3)) in data-scarce areas where bathymetry data doesn't exist (Fernández et al., 2016; Lewis et al., 2013; Schumann et al., 2014a, 2014b). Fernández et al. (2016) calculated the depth of the Logone by estimating $r$ and $p$ as parameters obtained by fitting a curve to the channel cross-sections data from (Evans, 1999). The depth of the channel was defined as

Depth $=r \times$ Width $^{p}$

To limit model complexity, we used a constant depth for each unique channel region. The Logone River was divided into two regions (approximately upstream and downstream of Logone-Gana), and all other river channels were defined as independent regions. The mean value of depths for the two Logone regions obtained from Fernández et al. (2016) were used. The upstream Logone channel depth was increased from its initial value $(4.1 \mathrm{~m})$ to $4.3 \mathrm{~m}$ to curtail overbank flooding in some regions. All other channels were calibrated to have a linear relationship with the width ( $p=1$ ), with $r$ ranging from 0.03 to 0.12 (resulting depth values ranged from $2 \mathrm{~m}$ to $3 \mathrm{~m}$ ).

We calibrated the value of Manning's $n$ such that the simulated flow of water on the floodplain matched the observations from classified Landsat imagery. Since depressions and floodplain were known to have dense vegetation in them while flooded, we started with a Manning's coefficient of $0.1 \mathrm{~s} / \mathrm{m}^{1 / 3}$ (Chow, 1959). However, with that $n$, the flood receded quickly, and the floodplain was dry much before the observations suggested. We increased the roughness coefficient for the floodplain to 0.3 , and the depressions to 0.25 so that the floodplain retained water for longer.

\subsubsection{Evaluation of the Logone model}

3.3.5.1. River flow. We used the discharge measurements at Logone Gana to compare and evaluate the performance of the Logone model. The accuracy of the simulation was evaluated by using the NashSutcliffe Efficiency (Nash and Sutcliffe, 1970). Nash-Sutcliffe Efficiency (NSE) is defined as (Eq. (4)):

$E=1-\frac{\sum_{i=1}^{n}\left(O_{i}-M_{i}\right)^{2}}{\sum_{i=1}^{n}\left(O_{i}-M\right)^{2}}$

where $\mathrm{O}$ refers to the observations and $\mathrm{M}$ refers to model predictions.

3.3.5.2. Inundation area. We used 40 flood inundation maps from multi-temporal Landsat ETM + imagery between 2001 and 2007 to assess the performance of the Logone model in producing flood inundation extents. We used 13 flood inundation maps in 2006 (January to December) for manual calibration of the DEM, and the rest to evaluate the performance of the model. In the simulation period between 2001 and 2007, we consider 2006 as calibration period and 2001-2005 and 2007 as evaluation period. We chose 2006 for calibration because we had images in the dry season, the flooding season and the flood recession season. Landsat images of the floodplain between July to September, when the floods start, that are clear of cloud cover are rare and limited the data we could use for this period.
To produce flood inundation maps from the Landsat images, the following process was performed. First, the missing data in the images from Landsat 7 images due to the failure of the Scan Line Corrector (SLC) instrument on-board was handled by using a gap-filling method. The method involved filling the no-data pixels in Landsat ETM + SLCoff images with the linear least square regression analysis of their SLCon counterparts (Fernández et al., 2016). Landsat 7 SLC-on image on 21 October 2001 was used in a Iterative Self-organizing Data Analysis (ISODATA) classifier to extract and mask out open waters on Lake Maga and the Logone River. Clouded areas and cloud-shadowed areas were masked by a $3 \times 3$ window size majority analysis where blue reflectance is greater than 0.2 (Fernández et al., 2016; Sakamoto et al., 2007). Flood extents were delineated by using a threshold-based classification of the short-wave infrared (SWIR) band (Landsat ETM + band 7) similar to Fernández et al. (2016) and Westra and De Wulf (2009).

We compared the model predicted flood inundation maps with the satellite observed flood inundation to asses the spatial performance of the model. We used two commonly used evaluation measures: critical success index (CSI) and hit rate (Aronica et al., 2002; Hawker et al., 2018; Sampson et al., 2015; Schaefer, 1990; Schumann et al., 2016). When flood predictions are compared with observations, we have four classes: True Positive (TP; flooded predicted as flooded, or hit), True Negative (TN; non flooded predicted as non flooded), False Positive (FP; non flooded predicted as flooded, or false alarm) and False Negative (FN; flooded predicted as non flooded, or miss). CSI is a measure of accuracy when TN is not considered (Eq. (5)). It is sensitive to hits while penalizing both misses and false alarms.

$C S I=\frac{T P}{T P+F P+F N}$

CSI values range from 0 to 1 where a value of 1 indicates that the model is in full agreement with the observations. The hit rate gives the fraction of flooded area that is correctly predicted by the model (Eq. (6)). The values range from 0 to 1 ; higher value indicates that the model predicts flood inundation better.

Hit rate $=\frac{T P}{T P+F N}$

We calculated the evaluation statistics only for the flooding season. For this purpose, we consider September to January as the flooded season and February to August as the dry season.

\subsubsection{Comparison with a "no canal" simulation}

We compared two scenarios, one with and one without canals, and examined what effect canals had on flood dynamics in the depressions. To understand the role of canals on the floodplain, we simulated the Logone model without any canals. All the parameters were kept the same, except for the canals. This "no-canal" simulation was then compared with the original simulation with canals in terms of flood inundation area, flood volume and timing of flood recession in the depressions.

\section{Results and discussion}

\subsection{Bara: Comparison of model simulations and field observations}

The field data collected in 2014 showed there was a difference between the rate of recession in the river and the other parts of the system. The river stage reduced by $\sim 1 \mathrm{~m}$ while the water levels in the floodplain, depression and fish canals reduced only by $\sim 0.4 \mathrm{~m}$ in the two weeks of observations during flood recession. The fishnet structure in the model was used to capture this dynamic of the system. Fig. 5 shows the recession rates in all the features of the floodplain for the collected field data as well as the model. The plot shows the depth anomaly with respect to water level on day one of measurement. The 


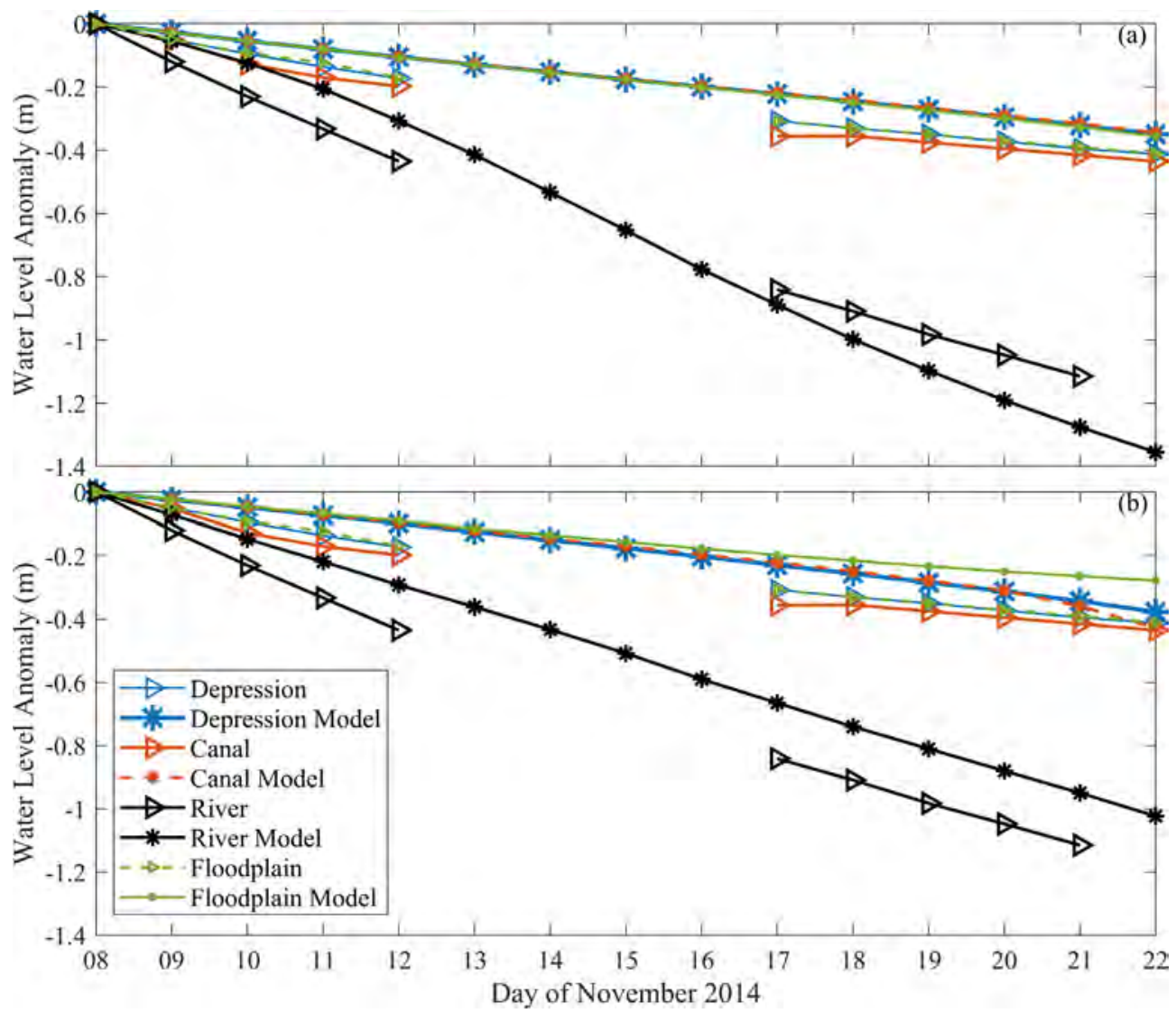

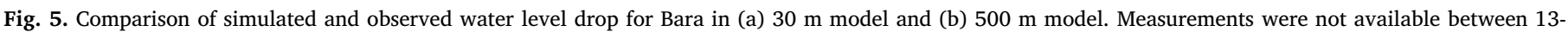
November and 16-November 2014.

Table 1

Observed and Simulated Difference between November-8-2014 and November22-2014 Water Levels in Various Floodplain Features at Bara. NSE gives the Nash-Sutcliffe Efficiency of the Simulated Water Level Difference w.r.t Observed for the 15-day Period.

\begin{tabular}{llllll}
\hline Feature & Measured (m) & $\begin{array}{l}\text { Fine Resolution Model } \\
(30 \mathrm{~m}) \\
\text { Simulated }(\mathrm{m})\end{array}$ & NSE & $\begin{array}{l}\text { Coarse Resolution Model } \\
(500 \mathrm{~m}) \\
\text { Simulated (m) }\end{array}$ & NSE \\
\hline River & 1.12 & 1.28 & 0.93 & 0.95 & 0.88 \\
Fish canal & 0.44 & 0.34 & 0.61 & 0.43 & 0.69 \\
Depression & 0.41 & 0.35 & 0.80 & 0.38 & 0.84 \\
Floodplain & 0.41 & 0.36 & 0.83 & 0.28 & 0.56 \\
\hline
\end{tabular}

slower recession rates in the floodplain, depression and fish canal compared to that in the river channel is evident. Table 1 shows the difference in water depth in the different features of the floodplain between day 1 and day 15 of the measurements. The corresponding model simulated change in water depth, and the NSE of simulated time series are also shown. It shows that the water drops a little slower in the model initially, but achieves the observed water level drop by the end of the measurement period. The different recession rate of the river from the other features was effectively captured in the coarse resolution model as well (Fig. 5(b)). The water depth difference in the observations and model, and their corresponding NSE is shown in Table 1 for the various features of the floodplain. The range of NSE is from 0.56 to 0.88 , which shows that the performance of the coarse resolution model is similar to that of the fine resolution model (NSE range 0.61-0.93), and has managed to capture the floodplain dynamics in the coarse resolution model. The use of $500 \mathrm{~m}$ resolution model to study the entire floodplain is justified by this result that the $500 \mathrm{~m}$ model when run at Bara still reproduces the water levels observed in the field, with a similar precision as the $30 \mathrm{~m}$ model.

In the floodplain, fishnet installed in fish canals have an obstruction made from sandbags and a screen made from twigs and tree branches which slows down the flow of water from the fish canal to the river. The fishnet structure we incorporated in the model successfully captured this by creating a drop across the fishnet. Fig. 6 shows the water drop across the fishnet on three days during the flood recession. It shows that there is a considerable drop caused by the fishnet as the flood recession progresses.

\subsection{Logone floodplain}

\subsubsection{Flow, mass balance}

The Logone Floodplain receives water from the Logone River and loses most water due to evaporation. Fig. 7 shows the modeled mean mass balance for the six-year study period. The mean volume difference between the input and output flows in the model is $0.79 \%$. We assumed that all the precipitation on the floodplain either infiltrated or evaporated, and ignored its effect. Fig. 7 does not show evaporation as a major flux; however, if we consider the modeled evaporation along with the precipitation that has evaporated, it becomes a major flux on the floodplain

We studied the dynamics of components of water balance by looking at the entire time series of discharge and evaporation. The model inflow and outflow for the entire time series are shown in Fig. 8(a), the calibration period in the time series is shaded in gray. There is a noticeable lag between the peak inflow and outflow discharges, with a mean of 29 days and a standard deviation of 10.39 days as the water has to traverse over $200 \mathrm{~km}$ along the river between the inflow and outflow locations. The evaporation in the floodplain is shown in Fig. 8(b). The peak evaporation occurs around November, 


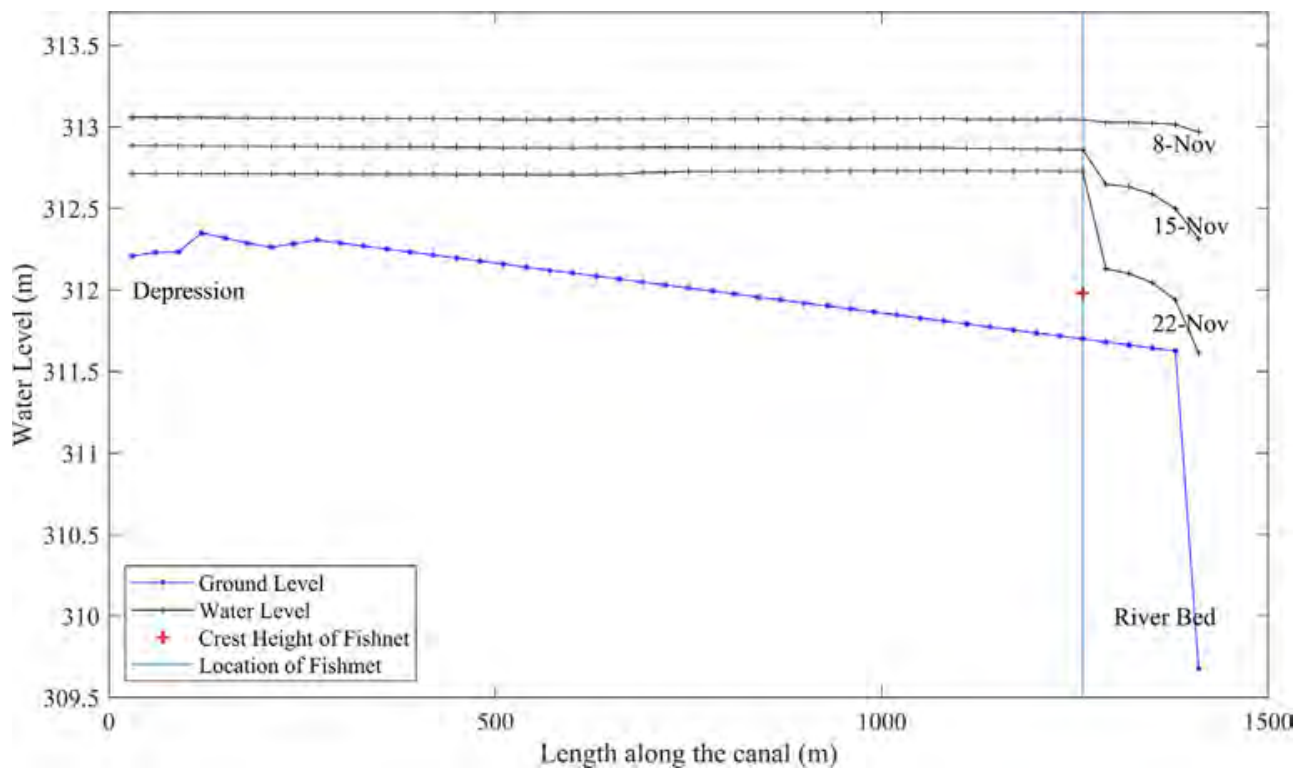

Fig. 6. Water drop across the fishnet during flood recession.

corresponding to when there is a peak flood. In the summer months, even though potential evapotranspiration is very high, actual evapotranspiration is quite low as water in confined to the river channels and Lake Maga.

Fig. 9 shows the time series of observed and simulated discharge at Logone Gana. There was no recorded discharge between June 2nd and October 30th 2006. The model accurately simulated the discharge at Logone-Gana. The difference between modeled and observed discharge was less than $100 \mathrm{~m}^{3} / \mathrm{s}$ more than $85 \%$ of the time. However, it should be noted that peak discharge is generally under-estimated in the model at Logone Gana. The NSE of discharge prediction at Logone Gana was 0.94. The accurate prediction of discharge at Logone Gana means that the model also accurately predicted the amount of water on the floodplain between Katoa and Logone Gana.

\subsubsection{Flood inundation}

We compared the model predicted inundation maps to those derived from satellite observations. Over the entire model domain, the comparison between observed and simulated inundated area is shown in Fig. 10. The gray area shows the calibration period, meaning the
Landsat-derived flood maps obtained during this time period was used for the manual calibration of the DEM. The observed and simulated inundated area had a Pearson correlation coefficient ( $\mathrm{r}$ ) of 0.94 , and coefficient of determination $\left(\mathrm{R}^{2}\right)$ of 0.81 . The model does not capture the peak in 2001, 2002 and 2005, but it captures the receding inundated area accurately.

The accurate prediction of flow at Logone Gana (shown in Fig. 9) means that the model also accurately predicts the channel to floodplain flow due to overbank flooding. This result is reinforced in Fig. 10, where the model again accurately predicts the magnitude of inundated area. Comparison between observed and simulated patterns of flood inundation is shown in Fig. 11(a) to (f) shows the flood inundation patterns during the flooded season of the calibration period of 2006. It shows that the model captures the flood inundation pattern quite well. The spatial mismatch is primarily due to the quality of topographic data, and justifies the use of manual calibration to adjust the DEM. Although manual calibration of the DEM improved the spatial performance of the model, there is still room for improvement. Recent methods like Mason et al. (2016) and Shastry and Durand (2019) could potentially be used to improve the DEM, and hence spatial performance

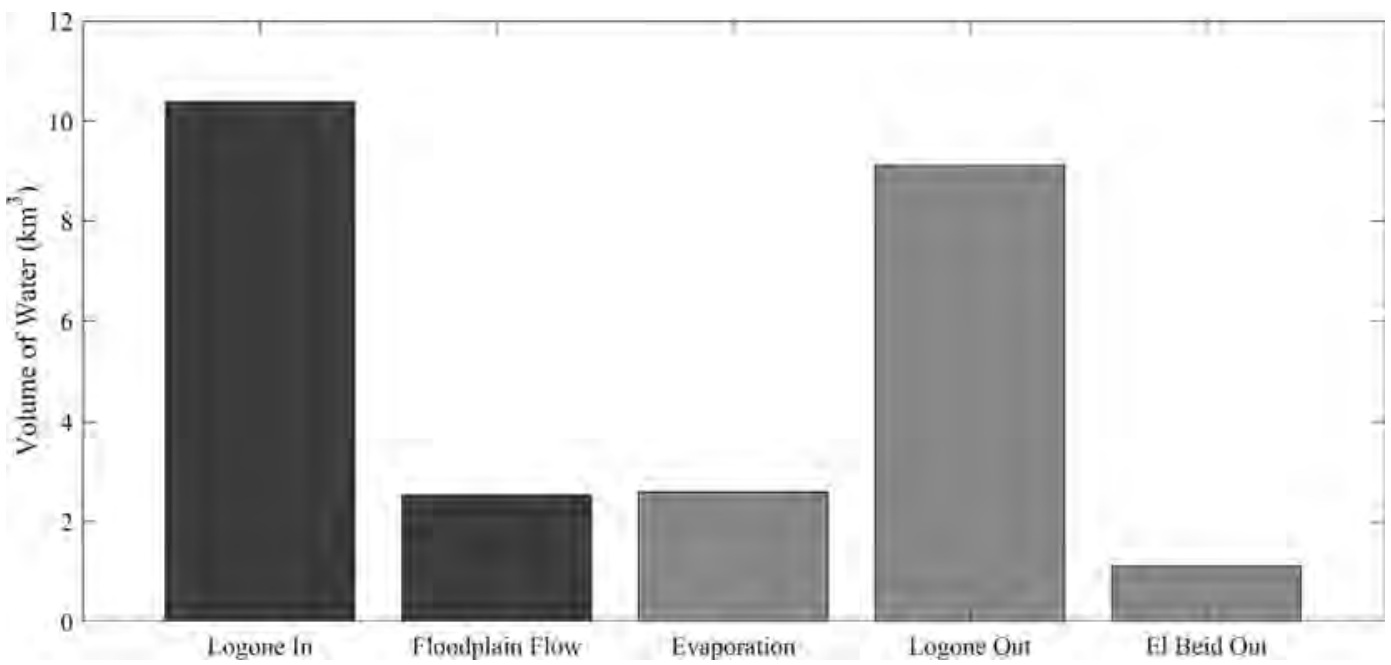

Fig. 7. Mean annual mass balance across the model domain between 2001 and 2007. Dark gray is water entering the model domain and light gray is water exiting the model domains. 

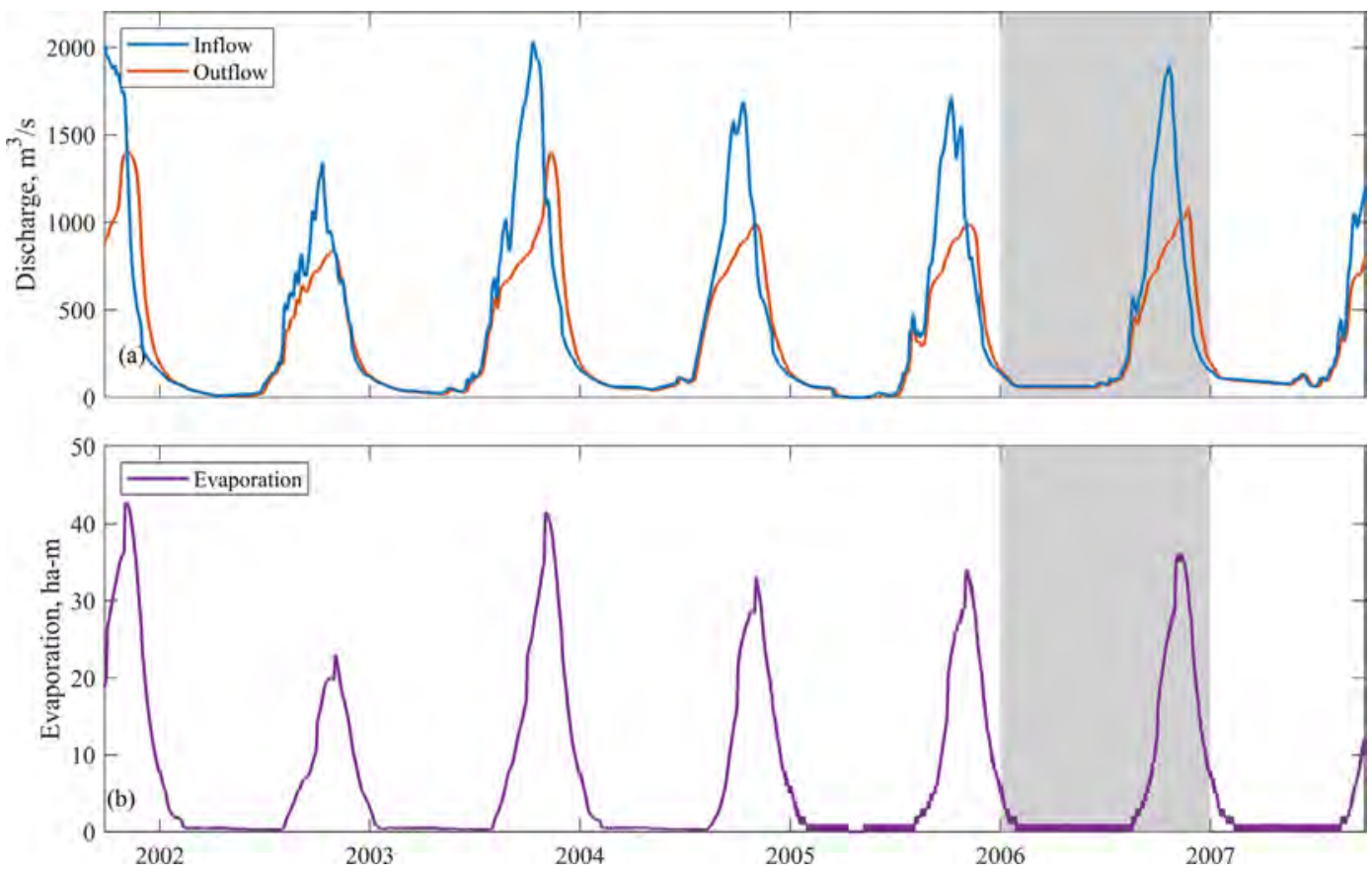

Fig. 8. (a) Inflow and outflow discharge time series in the Logone River at inlet and outlet of the model domain (b) Evaporation time series from the model for the model domain.

of the model.

The spatial patterns in two December maps (Fig. 11(e) and (f)) show that the movement of flood wave in the model is quicker than observed along the West side of the Logone River, and much slower on the East side. This could be because of difference in vegetation between the two regions during the flooded season. We use a constant high value of Manning's coefficient for the entire floodplain to account for vegetation on the West side of the Logone River. On the East side of the Logone River, the model holds on to the water for longer because of this. However, the conclusions of this paper regarding the depressions and fish canals on the West side are not affected by this. Fig. 11(g) to (l) show the flood inundation patterns on the days of peak flood from satellite imagery between 2001 and 2005. The observed peak flooded imagery occurs in the months of October and November. There are two available satellite images during this period in 2005, and both are shown.

We analyzed the spatial accuracy of predicted flood inundation maps by comparing them to satellite derived observations. Table 2 shows CSI and hit rate values for calibration and validation periods. The mean CSI during calibration and validation was 0.33 and 0.25 respectively, and the mean hit rate during calibration was 0.46 , and during validation was 0.32 . The mean values are lower due to the fact that flood recession in the model is much quicker than observed; this can be clearly seen in Fig. 11(e) and (f). However, the model captures the peak flood inundation pretty well. In 2006, the peak inundation is captured with a hit rate of 0.71 . During the evaluation period, the maximum hit rate is 0.67 during the peak of 1 -November 2005. It should be noted that the model does not capture the peaks in terms of discharge (Fig. 9) and magnitude of inundated area (Fig. 10), and these peaks may be captured if the spatial prediction capability at the peaks could be further improved.

\subsubsection{Impact of fishnets and fish canals on water storage in depressions}

The effect of the fishnet structure on the flow in the fish canal in Bara depression in the large-scale Logone model is shown in Fig. 12. It shows the water surface elevation along the length of the fish canal on

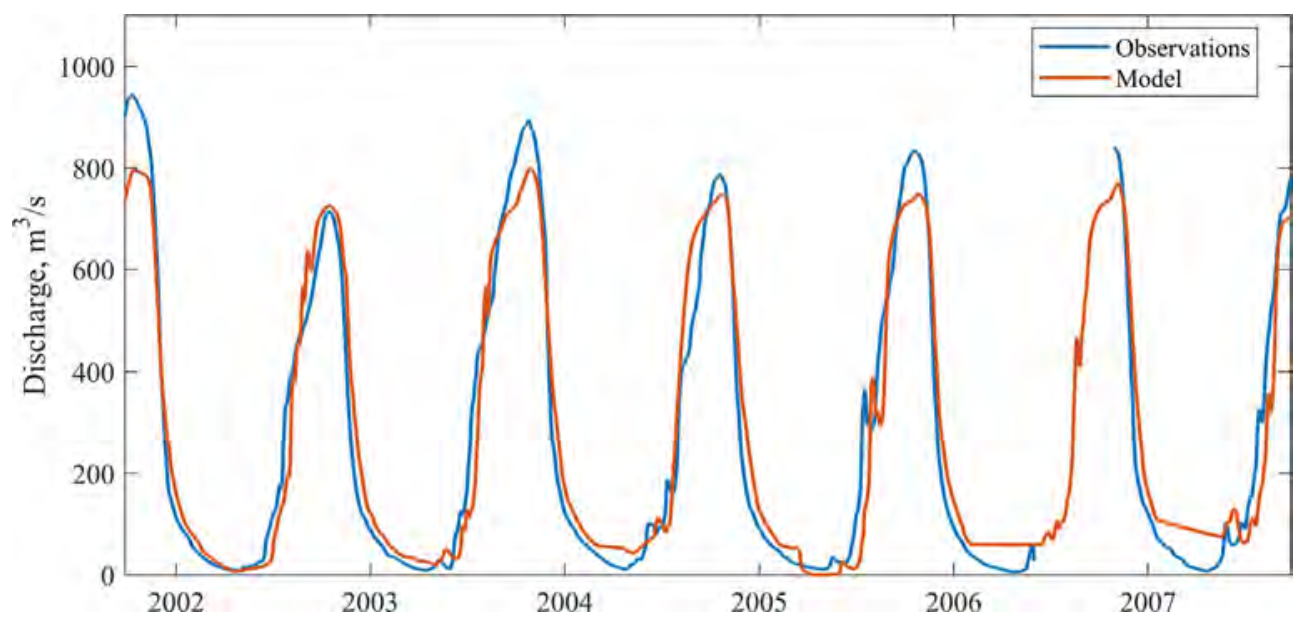

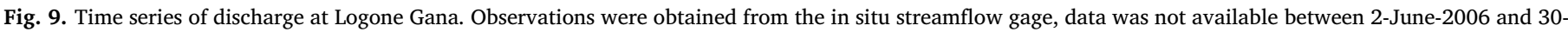
Oct-2006s. 


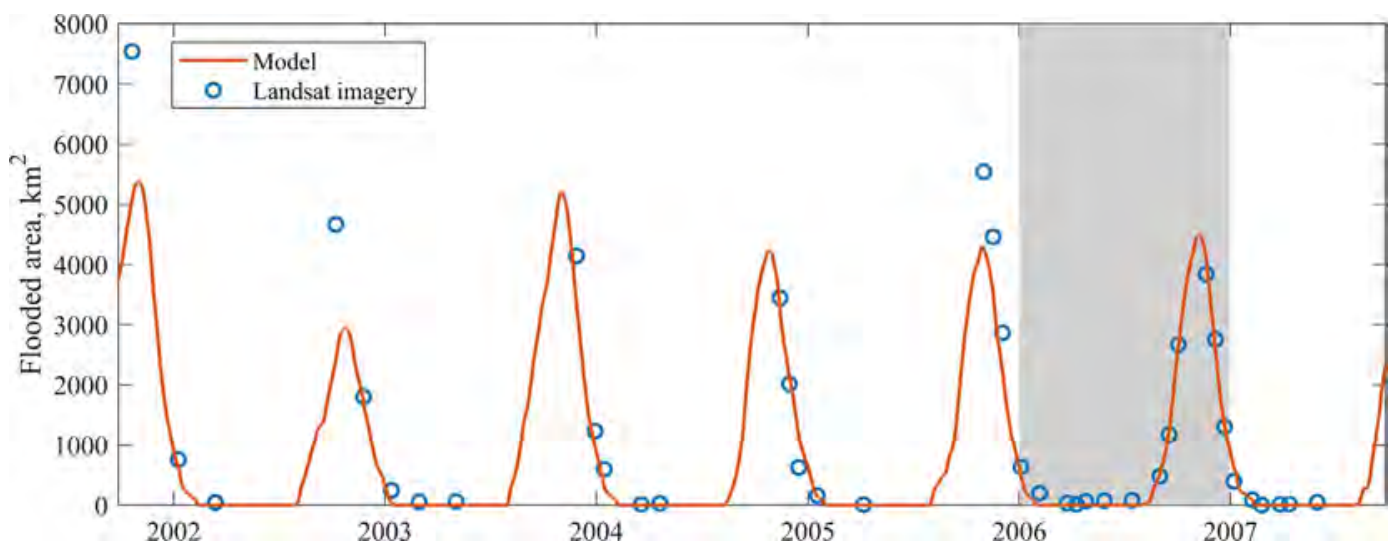

Fig. 10. Flood inundation time series for the Logone Floodplain. Shaded area represents the calibration period.

three days during the flood recession. The water drop across the fishnet structure is clearly seen. The fishnet structure slows down the flow of water from the fish canal to the river, and the model is able to capture this effectively.

Fig. 13 shows timeseries of water storage in depressions from two model simulations, with and without including fish canals. Fig. 13 also shows the total inundated area within all depressions, based on the Landsat inundated area maps. While both model simulations overestimate the duration of inundation, the simulation including canals is most likely closer to reality. For example, in 2006, for the simulation including canals, by December 3 the total depression storage was 763 ha-m, around half the maximum value (1542 ha-m, on October 14).
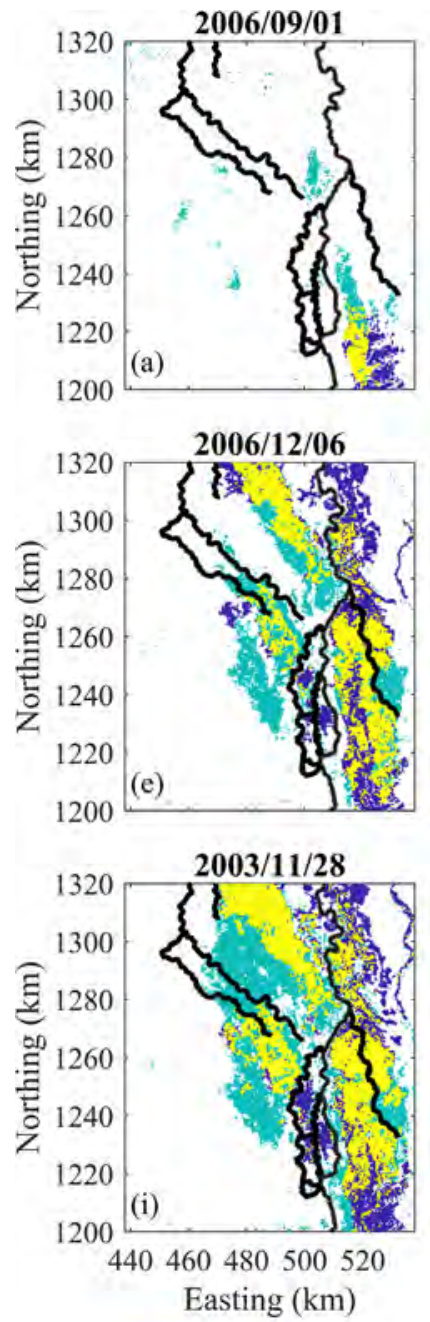

Observed \& Modeled

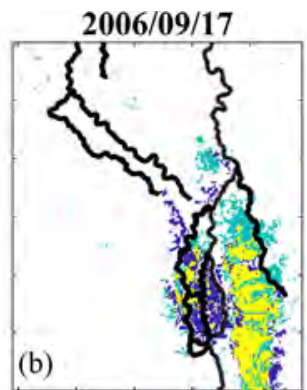

2006/12/22
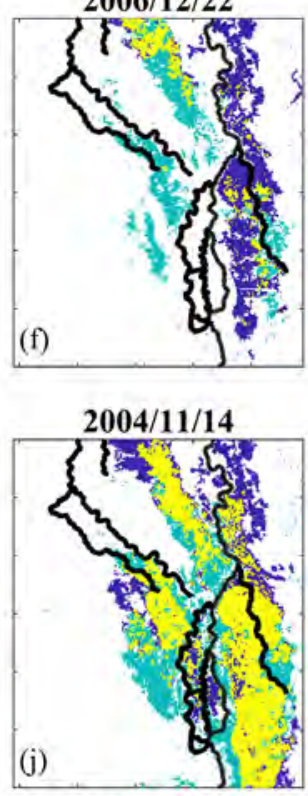

440460480500520

Easting $(\mathrm{km})$

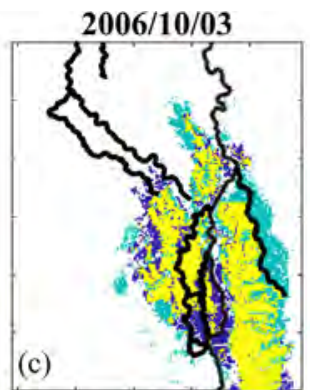

2001/10/21

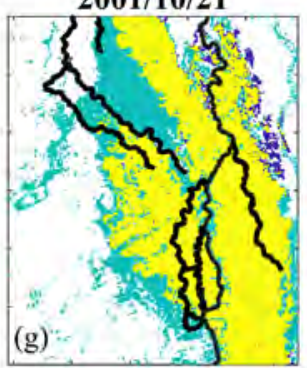

(h)

(d)
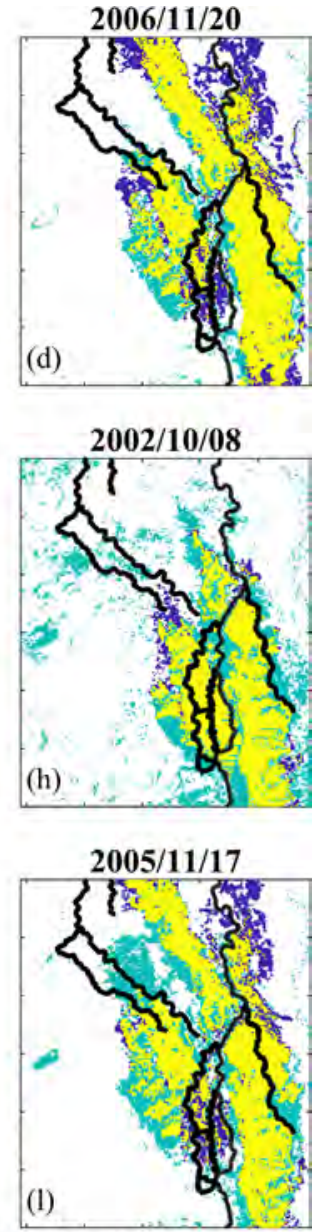

(k)

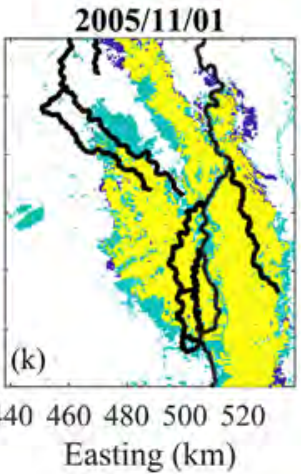

440460480500520

Easting (km)

Observed

Modeled

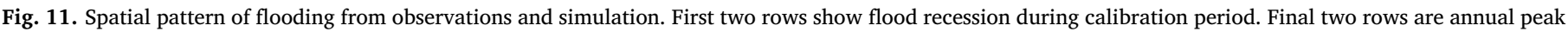
floods during evaluation period. 
Table 2

Evaluation Statistics for Modeled Flood Inundation Prediction Compared to Satellite Imagery for the Calibration and Evaluation Period.

\begin{tabular}{|c|c|c|c|c|c|c|c|c|}
\hline & \multicolumn{4}{|c|}{ Calibration Period } & \multicolumn{4}{|c|}{ Evaluation Period } \\
\hline & Min & Max & Mean & Standard deviation & Min & Max & Mean & Standard deviation \\
\hline Critical Success Index (CSI) & 0.15 & 0.54 & 0.33 & 0.16 & 0 & 0.63 & 0.25 & 0.22 \\
\hline Hit Rate & 0.24 & 0.71 & 0.46 & 0.19 & 0 & 0.67 & 0.29 & 0.24 \\
\hline
\end{tabular}

The simulation that neglects canals does not reach the half-maximum value until more than a month later, on January 12, 2007. The Landsat observation on November 20 almost perfectly captured the halfway point of the depression inundation $\left(5.8 \mathrm{~km}^{2}\right.$, down from $12.2 \mathrm{~km}^{2}$ on October 3). The observations reach the halfway point around the same time as the simulation including canals; the simulation without canals retains its water too long. Indeed, the Landsat observation on January 7, 2007 shows that the depressions were essentially dry $\left(<0.1 \mathrm{~km}^{2}\right)$, when the simulation without canals is still half full. Similar dynamics exist for the other years; the date depressions are empty is an average of $\sim 29 \pm 2$ days earlier in simulations that include canals (see Fig. 13). Thus, simulations including fish canals more closely represents the correct inundation dynamics within the depressions. Duration of inundation in the depressions is a critical variable for floodplain fisheries, as the duration of inundation in depressions governs fish growth. The quicker recession in depressions, as noticed in model simulations and confirmed by observations, shortens the growing season for fish, resulting in lower fish biomass at the time of recession when most of the fishing occurs.

\section{Conclusions}

The goal of the study was to evaluate the strategy of using a hydrodynamic model with sub-grid scale channels and structures to represent small-scale anthropogenic controls on floodplain dewatering at the scale of the entire Logone Floodplain. This was accomplished using the LISFLOOD-FP model applied to the Logone Floodplain in Cameroon. We built a fine resolution model $(30 \mathrm{~m})$ of one depression (Bara) with fish canals and fishnets, which were successful in approximating the physical processes on the floodplain. We reproduced the change in water levels across all features (floodplain, depression, fish canals and river channel) as observed during two weeks of flood recession. We upscaled this model to a larger resolution of $500 \mathrm{~m}$ and found that, with the help of sub-grid parametrization of fish canals and depressions, we were still able to successfully capture the processes on the floodplain. It is noteworthy that a $500 \mathrm{~m}$ resolution hydrodynamic model was capable of accurately representing small-scale features like fish canals that are a few meters wide, and fishnets constructed across these fish canals. We applied this strategy of representing fish canals and depressions as sub-grid features to the entire floodplain to assess their impact on the flow patterns. We found that fish canals are critical for modeling inundation timing in the depressions: model simulations excluding canals emptied around a month too late, compared to satellite observations, with important implications for using such models to inform fish growth and population. Fishing is a major source of income in the Logone Floodplain, and lower fish catches would have a huge impact on the local economy. These modeling strategies enable us to quantify small-scale processes in a computationally efficient model. These models can be coupled with fisheries model (like described in Welcomme and Hagborg (1977)), to study the impacts of these smallscale features on floodplain fisheries.

\section{CRediT authorship contribution statement}

Apoorva Shastry: Conceptualization, Methodology, Validation, Formal analysis, Investigation, Visualization, Writing - original draft, Writing - review \& editing. Michael Durand: Conceptualization, Methodology, Supervision, Writing - original draft, Writing - review \& editing. Jeffrey Neal: Software, Supervision. Alfonso Fernández: Resources, Supervision. Sui Chian Phang: Resources, Supervision. Brandon Mohr: Investigation. Hahn Chul Jung: Resources. Saïdou Kari: Resources. Mark Moritz: Resources, Supervision, Funding acquisition. Bryan G. Mark: Supervision. Sarah Laborde: Resources, Supervision. Asmita Murumkar: Resources, Supervision. Ian Hamilton: Supervision.

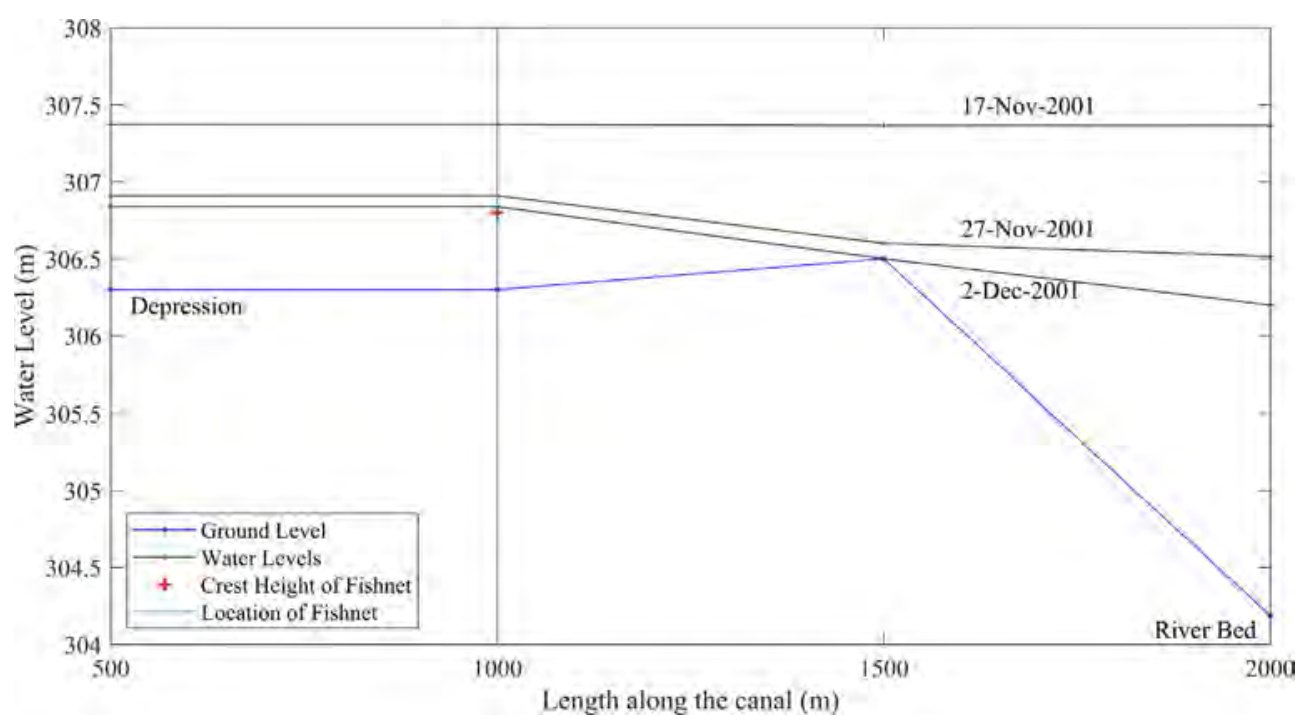

Fig. 12. Water drop across the fishnet at Bara in the Logone model. 


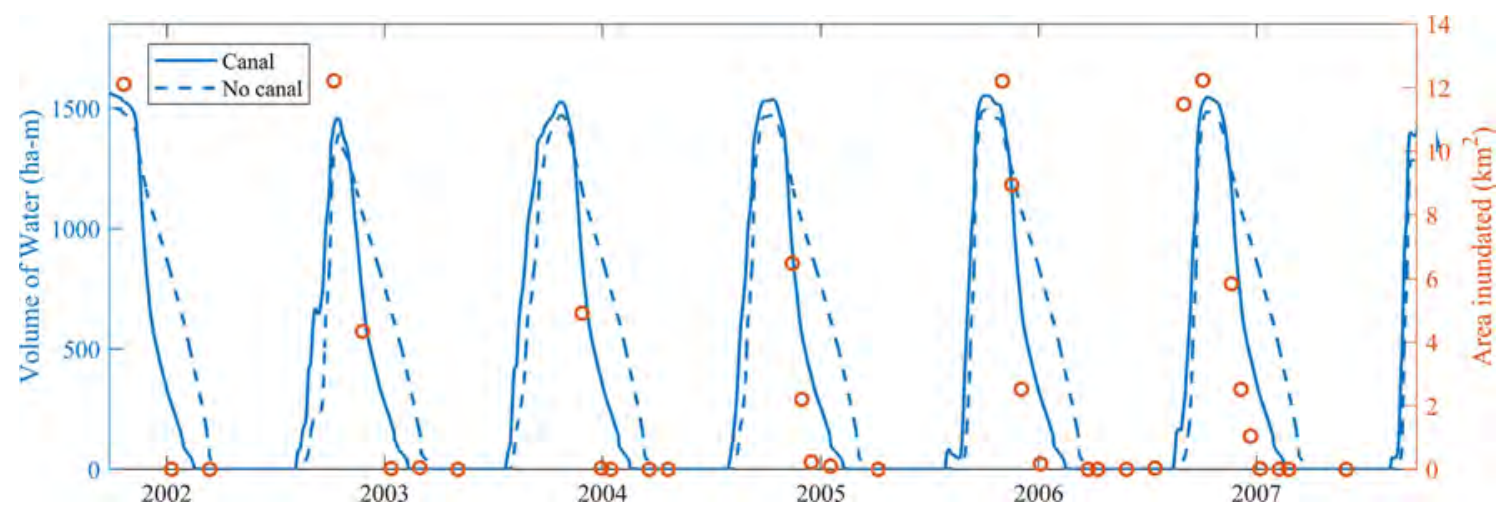

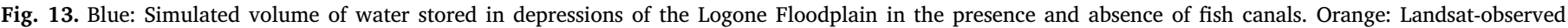
inundated area in the depressions.

\section{Declaration of Competing Interest}

The authors declare that they have no known competing financial interests or personal relationships that could have appeared to influence the work reported in this paper.

\section{Acknowledgements}

This study was funded by the National Science Foundation grant, Dynamics of Coupled Natural and Human Systems (CNH) Program: Exploring social, ecological and hydrological regime shifts in the Logone Floodplain, Cameroon, Mark Moritz (PI), Michael Durand, Ian Hamilton, Bryan Mark, Ningchuan Xiao (BCS-1211986). We are grateful to Sara Vassolo for discharge data, and the CARPA field team for field data collection.

\section{References}

Annis, A., Nardi, F., Morrison, R.R., Castelli, F., 2019. Investigating hydrogeomorphic floodplain mapping performance with varying DTM resolution and stream order. Hydrol. Sci. J. 64, 525-538. https://doi.org/10.1080/02626667.2019.1591623.

Aronica, G., Bates, P.D., Horritt, M.S., 2002. Assessing the uncertainty in distributed model predictions using observed binary pattern information within GLUE. Hydrol. Process. 16, 2001-2016. https://doi.org/10.1002/hyp.398.

Balkham, M., Fosbeary, C., Kitchen, A., Rickard, C., 2010. Culvert Design and Operation Guide (C689). CIRIA.

Bates, P.D., Dawson, R.J., Hall, J.W., Horritt, M.S., Nicholls, R.J., Wicks, J., Hassan, M.A. Ali Mohamed, 2005. Simplified two-dimensional numerical modelling of coastal flooding and example applications. Coast. Eng. 52, 793-810. https://doi.org/10. 1016/j.coastaleng.2005.06.001.

Bates, P.D., De Roo, A.P.J., 2000. A simple raster-based model for flood inundation simulation. J. Hydrol. 236, 54-77. https://doi.org/10.1016/S0022-1694(00)00278-X.

Bates, P.D., Horritt, M.S., Fewtrell, T.J., 2010. A simple inertial formulation of the shallow water equations for efficient two-dimensional flood inundation modelling. J. Hydrol. 387, 33-45. https://doi.org/10.1016/j.jhydrol.2010.03.027.

Blöschl, G., Sivapalan, M., 1995. Scale issues in hydrological modelling: a review. Hydrol. Process. 9, 251-290. https://doi.org/10.1002/hyp.3360090305.

Bockelmann, B.N., Fenrich, E.K., Lin, B., Falconer, R.A., 2004. Development of an ecohydraulics model for stream and river restoration. Ecol. Eng. 22, 227-235. https:// doi.org/10.1016/j.ecoleng.2004.04.003.

Camporese, M., Paniconi, C., Putti, M., Orlandini, S., 2010. Surface-subsurface flow modeling with path-based runoff routing, boundary condition-based coupling, and assimilation of multisource observation data. Water Resour. Res. 46. https://doi.org/ 10.1029/2008WR007536.

Casas-Mulet, R., Alfredsen, K., Killingtveit, A., 2014. Modelling of environmental flow options for optimal Atlantic salmon, Salmo salar, embryo survival during hydropeaking. Fish. Manag. Ecol. 21, 480-490. https://doi.org/10.1111/fme.12097.

Chow, V Te, 1959. Open-channel Hydraulics. McGraw-Hill Book Company ISBN 07010776-9.

Delclaux, F., Haas, E., Rouché, E., 2010. Satellite monitoring of Yaere flood plain dynamics (North Cameroon). In: Global Change: Facing Risks and Threats to Water Resources. International Association of Hydrological Sciences, pp. 435-443.

Delclaux, F., Seignobos, C., Liénou, G., Genthon, P., 2011. Water and people in the Yaéré floodplain (North Cameroon). In: Floodplains: Physical Geography, Ecology and Societal Interactions. Nova Science Publishers, Inc., pp. 1-27.

DeVries, P., Fetherston, K.L., Vitale, A., Madsen, S., 2012. Emulating riverine landscape controls of beaver in stream restoration. Fisheries 37, 246-255. https://doi.org/10.
1080/03632415.2012.687263.

Evans, S.Y., 1999. Logone Floodplain Model Study Report.

Evans, S.Y., Loth, P., 2004a. Hydrology of the Waza Logone area. In: Loth, P. (Ed.), The Return of the Water: Restoring the Waza Logone Floodplain in Cameroon. IUCN, Gland, Switzerland and Cambridge, UK, pp. 33-37.

Evans, S.Y., Loth, P., 2004b. The wider context. In: Loth, P. (Ed.), The Return of the Water Restoring the Waza Logone Floodplain in Cameroon. IUCN, Gland, Switzerland and Cambridge, UK, pp. 27-32.

Fernández, A., Najafi, M.R., Durand, M., Mark, B.G., Moritz, M., Jung, H.C., Neal, J., Shastry, A., Laborde, S., Phang, S.C., Hamilton, I.M., Xiao, N., 2018. Corrigendum to 'Testing the skill of numerical hydraulic modeling to simulate spatiotemporal flooding patterns in the Logone floodplain, Cameroon' [Journal of Hydrology, volume 539 (2016) 265-280]. J. Hydrol. 562, 833-834. https://doi.org/10.1016/J. JHYDROL.2018.06.012.

Fernández, A., Najafi, M.R., Durand, M., Mark, B.G., Moritz, M., Jung, H.C., Neal, J., Shastry, A., Laborde, S., Phang, S.C., Hamilton, I.M., Xiao, N., 2016. Testing the skill of numerical hydraulic modeling to simulate spatiotemporal flooding patterns in the Logone floodplain, Cameroon. J. Hydrol. 539, 265-280. https://doi.org/10.1016/j. jhydrol.2016.05.026.

Finnegan, N.J., Roe, G., Montgomery, D.R., Hallet, B., 2005. Controls on the channel width of rivers: implications for modeling fluvial incision of bedrock. Geology 33, 229-232. https://doi.org/10.1130/G21171.1.

Flint, J.J., 1974. Stream gradient as a function of order, magnitude, and discharge. Water Resour. Res. 10, 969-973, https://doi.org/10.1029/WR010i005p00969.

Frasson, R.P. de M., Pavelsky, T.M., Fonstad, M.A., Durand, M.T., Allen, G.H., Schumann, G., Lion, C., Beighley, R.E., Yang, X., 2019. Global relationships between river width, slope, catchment area, meander wavelength, sinuosity, and discharge. Geophys. Res. Lett. https://doi.org/10.1029/2019GL082027.

García, A., Jorde, K., Habit, E., Caamaño, D., Parra, O., 2011. Downstream environmental effects of dam operations: changes in habitat quality for native fish species. River Res. Appl. 27, 312-327. https://doi.org/10.1002/rra.1358.

Gippel, C.J., Stewardson, M.J., 1998. Use of wetted perimeter in defining minimum environmental flows. Regul. Rivers Res. Manag. 14, 53-67. https://doi.org/10.1002/ (sici)1099-1646(199801/02)14:1<53::aid-rrr476 > 3.3.co;2-q.

Hawker, L., Rougier, J., Neal, J., Bates, P., Archer, L., Yamazaki, D., 2018. Implications of simulating global digital elevation models for flood inundation studies. Water Resour. Res. 54, 7910-7928. https://doi.org/10.1029/2018WR023279.

Hirabayashi, Y., Mahendran, R., Koirala, S., Konoshima, L., Yamazaki, D., Watanabe, S., Kim, H., Kanae, S., 2013. Global flood risk under climate change. Nat. Clim. Chang. 3, 816-821. https://doi.org/10.1038/nclimate1911.

Jung, H.C., Alsdorf, D., Moritz, M., Lee, H., Vassolo, S., 2011. Analysis of the relationship between flooding area and water height in the Logone floodplain. Phys. Chem. Earth 36, 232-240. https://doi.org/10.1016/j.pce.2011.01.010.

Kennedy, A.B., Wirasaet, D., Begmohammadi, A., Sherman, T., Bolster, D., Dietrich, J.C., 2019. Subgrid theory for storm surge modeling. Ocean Model. 144, 101491. https:// doi.org/10.1016/j.ocemod.2019.101491.

Kim, D., Yu, H., Lee, H., Beighley, E., Durand, M., Alsdorf, D.E., Hwang, E., 2019. Ensemble learning regression for estimating river discharges using satellite altimetry data: Central Congo River as a Test-bed. Remote Sens. Environ. 221, 741-755. https://doi.org/10.1016/j.rse.2018.12.010.

Komi, K., Neal, J., Trigg, M.A., Diekkrüger, B., 2017. Modelling of flood hazard extent in data sparse areas: a case study of the Oti River basin, West Africa. J. Hydrol. Reg. Stud. 10, 122-132. https://doi.org/10.1016/j.ejrh.2017.03.001.

Laborde, S., Fernández, A., Phang, S.C., Hamilton, I.M., Henry, N., Jung, H.C., Mahamat, A., Ahmadou, M., Labara, B.K., Kari, S., Durand, M., Mark, B., Scholte, P., Xiao, N., Ziebe, R., Moritz, M., 2016. Social-ecological feedbacks lead to unsustainable lock-in in an inland fishery. Glob. Environ. Chang. 41, 13-25. https://doi.org/10.1016/j. gloenvcha.2016.08.004.

Landolt, G., 2010. Lost control, legal pluralism and damming the flood: changing institutions among the Musgum and Kotoko of the Village Lahai in the Waza-Logone Floodplain (Cameroon). In: Disputing The Floodplains: Institutional Change and The Politics of Resource Management in African Wetlands. https://doi.org/10.1163/ej. 9789004185326.i-454.47. 
Leopold, L.B., Maddock, T.J., 1953. The Hydraulic Geometry of Stream Channels and Some Physiographic Implications, Geological Survey Professional Paper 252

Laborde, S., Phang, S.C., Ahmadou, M., Henry, N., Fernández, A., Durand, M., Hamilton, I.M., Kari, S., Mahamat, A., Mark, B., Scholte, P., Shastry, A., Ziebe, R., Moritz, M., 2018. Co-producing research in the "Red Zone": Adaptation to fieldwork constraints with a transdisciplinary approach. Geogr. J. 184 (4), 369-383. https://doi.org/10. 1111/geoj.12264.

Lewis, M., Bates, P., Horsburgh, K., Neal, J., Schumann, G., 2013. A storm surge inundation model of the northern Bay of Bengal using publicly available data. Q. J. R. Meteorol. Soc. 139, 358-369. https://doi.org/10.1002/qj.2040.

Loth, P., 2004. The return of the water Restoring the Waza Logone floodplain in Cameroo.

Magilligan, F.J., 1992. Thresholds and the spatial variability of flood power during extreme floods. Geomorphology 5, 373-390. https://doi.org/10.1016/0169-555X(92) 90014-F.

Mason, D.C., Trigg, M., Garcia-Pintado, J., Cloke, H.L., Neal, J.C., Bates, P.D., 2016. Improving the TanDEM-X Digital Elevation Model for flood modelling using flood extents from Synthetic Aperture Radar images. Remote Sens. Environ. 173, 15-28. https://doi.org/10.1016/j.rse.2015.11.018.

Mitchell, S.A., 2013. The status of wetlands, threats and the predicted effect of global climate change: the situation in Sub-Saharan Africa. Aquat. Sci. 75, 95-112. https:// doi.org/10.1007/s00027-012-0259-2.

Moritz, M., Laborde, S., Phang, S.C., Ahmadou, M., Durand, M., Fernandez, A., Hamilton, I.M., Kari, S., Mark, B., Scholte, P., Xiao, N., Ziebe, R., 2016. Studying the Logone floodplain, Cameroon, as a coupled human and natural system. African J. Aquat. Sci. 41, 99-108. https://doi.org/10.2989/16085914.2016.1143799.

Naah, E., 1990. Hydrologie du Grand Yaére du Nord Cameroun. l'Université de Yaoundé.

Murumkar, A., Durand, M., Fernández, A., Moritz, M., Mark, B., Phang, S.C., Laborde, S., Scholte, P., Shastry, A., Hamilton, I., 2020. Trends and spatial patterns of 20th century temperature, rainfall and PET in the semi-arid Logone River basin, SubSaharan Africa. J. Arid Environ. 178. https://doi.org/10.1016/j.jaridenv.2020. 104168.

Nash, J.E., Sutcliffe, J.V., 1970. River flow forecasting through conceptual models part I-a discussion of principles. J. Hydrol. 10, 282-290. https://doi.org/10.1016/00221694(70)90255-6.

Neal, J., Schumann, G., Bates, P., 2012. A subgrid channel model for simulating river hydraulics and floodplain inundation over large and data sparse areas. Water Resour. Res. 48. https://doi.org/10.1029/2012WR012514.

Neal, J., Schumann, G., Fewtrell, T., Budimir, M., Bates, P., Mason, D., 2011. Evaluating a new LISFLOOD-FP formulation with data from the summer 2007 floods in Tewkesbury, UK. J. Flood Risk Manag. 4, 88-95. https://doi.org/10.1111/j.1753318X.2011.01093.x.

Nislow, K.H., Magilligan, F.J., Folt, C.L., Kennedy, B.P., 2002. Within-basin variation in the short-term effects of a major flood on stream fishes and invertebrates. J. Freshw. Ecol. 17, 305-308. https://doi.org/10.1080/02705060.2002.9663899.

O'Neill, S.J., Hulme, M., 2009. An iconic approach for representing climate change. Glob. Environ. Chang. 19, 402-410. https://doi.org/10.1016/j.gloenvcha.2009.07.004.

Park, C.C., 1977. World-wide variations in hydraulic geometry exponents of stream channels: an analysis and some observations. J. Hydrol. 33, 133-146. https://doi. org/10.1016/0022-1694(77)90103-2.

Pinter, N., Heine, R.A., 2005. Hydrodynamic and morphodynamic response to river engineering documented by fixed-discharge analysis, Lower Missouri River, USA. J. Hydrol. 302, 70-91. https://doi.org/10.1016/j.jhydrol.2004.06.039.

Rajib, A., Golden, H.E., Lane, C., Wu, Q., 2019. Surface depression water storage im proves continental scale modeling for watershed management. In: AGU Fall Meeting 2019.

Rodriguez, E., Morris, C., Belz, J., 2006. An assessment of the SRTM topographic productsa. Photogramm. Eng. Remote Sens. 72, 249-260 https://doi.org/0099-1112/ 06/7203-0249/\$3.00/0.

Rudorff, C.M., Melack, J.M., Bates, P.D., 2014a. Flooding dynamics on the lower Amazon floodplain: 1. Hydraulic controls on water elevation, inundation extent, and riverfloodplain discharge. Water Resour. Res. 50, 619-634. https://doi.org/10.1002/ 2013 WR014091.

Rudorff, C.M., Melack, J.M., Bates, P.D., 2014b. Flooding dynamics on the lower Amazon floodplain: 2. Seasonal and interannual hydrological variability. Water Resour. Res. 50, 635-649. https://doi.org/10.1002/2013WR014714.
Sakamoto, T., Van Nguyen, N., Kotera, A., Ohno, H., Ishitsuka, N., Yokozawa, M., 2007. Detecting temporal changes in the extent of annual flooding within the Cambodia and the Vietnamese Mekong Delta from MODIS time-series imagery. Remote Sens. Environ. https://doi.org/10.1016/j.rse.2007.01.011.

Sampson, C.C., Smith, A.M., Bates, P.B., Neal, J.C., Alfieri, L., Freer, J.E., 2015. A highresolution global flood hazard model. Water Resour. Res. 51, 7358-7381. https://doi. org/10.1002/2015WR016954.

Schaefer, J.T., 1990. The critical success index as an indicator of warning skill. Weather Forecast. 5, 570-575. https://doi.org/10.1175/1520-0434(1990) $005<0570$ :TCSIAA $>2.0$. CO; 2 .

Scholte, P., 2005. Floodplain Rehabilitation and the Future of Conservation \& Development. Adaptive management of success in Waza-Logone, Cameroon. Wageningen Research Centre, Wageningen University.

Schumann, Guy J.P., Andreadis, K.M., Bates, P.D., 2014a. Downscaling coarse grid hydrodynamic model simulations over large domains. J. Hydrol. 508, 289-298. https:// doi.org/10.1016/j.jhydrol.2013.08.051.

Schumann, G.J.P., Neal, J.C., Voisin, N., Andreadis, K.M., Pappenberger, F., Phanthuwongpakdee, N., Hall, A.C., Bates, P.D., 2013. A first large-scale flood inundation forecasting model. Water Resour. Res. 49, 6248-6257. https://doi.org/10. 1002/wrcr.20521.

Schumann, G.J.P., Stampoulis, D., Smith, A.M., Sampson, C.C., Andreadis, K.M., Neal, J.C., Bates, P.D., 2016. Rethinking flood hazard at the global scale. Geophys. Res. Lett. 43, 10249-10256. https://doi.org/10.1002/2016GL070260.

Schumann, G.J.P., Vernieuwe, H., De Baets, B., Verhoest, N.E.C., 2014b. ROC-based calibration of flood inundation models. Hydrol. Process. 28, 5495-5502. https://doi. org/10.1002/hyp.10019.

Schumm, S.A., 1956. Evolution of drainage systems and slopes in badlands at Perth Amboy, New Jersey. Bull. Geol. Soc. Am. 57, 597-646. https://doi.org/10.1130/ 0016-7606(1956)67[597:EODSAS]2.0.CO;2.

Seeber, K., 2013. Lake Chad Basin: Sustainable Water Management. 2nd Mission on Discharge Measurements at Chari, Logone and Koulambou River, Chad. Hannover.

Shastry, A., Durand, M., 2019. Utilizing flood inundation observations to obtain floodplain topography in data-scarce regions. Front. Earth Sci. 6. https://doi.org/10.3389/ feart.2018.00243.

Tarboton, D.G., Bras, R.L., Rodriguez-Iturbe, I., 1991. On the extraction of channel networks from digital elevation data. Hydrol. Process. 5, 81-100. https://doi.org/10. 1002/hyp.3360050107.

Thompson, J.R., Polet, G., 2000. Hydrology and land use in a Sahelian floodplain Wetland. Wetlands 20, 639-659. https://doi.org/10.1672/0277-5212(2000) 020[0639:HALUIA]2.0.CO;2.

Welcomme, R.L., Hagborg, D., 1977. Towards a model of a floodplain fish population and its fishery. Environ. Biol. Fishes 2, 7-24. https://doi.org/10.1007/BF00001412.

Westra, T., De Wulf, R.R., 2009. Modelling yearly flooding extent of the Waza- Logone floodplain in northern Cameroon based on MODIS and rainfall data 30, 5527-5548. https://doi.org/10.1080/01431160802672872.

Whipple, K.X., Tucker, G.E., 1999. Dynamics of the stream-power river incision model: implications for height limits of mountain ranges, landscape response timescales, and research needs. J. Geophys. Res. Solid Earth 104, 17661-17674. https://doi.org/10. 1029/1999jb900120.

Wing, O.E.J., Bates, P.D., Sampson, C.C., Smith, A.M., Johnson, K.A., Erickson, T.A., 2017. Validation of a $30 \mathrm{~m}$ resolution flood hazard model of the conterminous United States. Water Resour. Res. 53, 7968-7986. https://doi.org/10.1002/ 2017WR020917.

Wood, M., Hostache, R., Neal, J., Wagener, T., Giustarini, L., Chini, M., Corato, G., Matgen, P., Bates, P., 2016. Calibration of channel depth and friction parameters in the LISFLOOD-FP hydraulic model using medium-resolution SAR data and identifiability techniques. Hydrol. Earth Syst. Sci. 20, 4983-4997. https://doi.org/10. 5194/hess-20-4983-2016.

Yamazaki, D., Ikeshima, D., Tawatari, R., Yamaguchi, T., O'Loughlin, F., Neal, J.C., Sampson, C.C., Kanae, S., Bates, P.D., 2017. A high-accuracy map of global terrain elevations. Geophys. Res. Lett. 44, 5844-5853. https://doi.org/10.1002/ 2017 GL072874.

Yamazaki, D., Kanae, S., Kim, H., Oki, T., 2011. A physically based description of floodplain inundation dynamics in a global river routing model. Water Resour. Res. https://doi.org/10.1029/2010WR009726. 